\title{
Variability of phytoplankton and mesozooplankton biomass in the subtropical and tropical Atlantic Ocean
}

\author{
Z. Z. Finenko ${ }^{1}$, S. A. Piontkovski ${ }^{1,4, *}$, R. Williams ${ }^{2}$, A. V. Mishonov ${ }^{3}$ \\ ${ }^{1}$ Institute of Biology of the Southern Seas, 2 Nakhimov Ave., Sevastopol 99011, Ukraine \\ ${ }^{2}$ Plymouth Marine Laboratory, Prospect Place, Plymouth PL1 3DH, United Kingdom \\ ${ }^{3}$ Department of Oceanography, Texas A \& M University, College Station, Texas 77843-3146, USA \\ ${ }^{4}$ Present address: Marine Sciences Research Center, Stony Brook University, Stony Brook, New York 11794-5000, USA
}

\begin{abstract}
Data from over 40 yr (1950-1992) of expeditions to the Atlantic Ocean are summarised in the form of macroscale contour maps between $40^{\circ} \mathrm{N}$ and $40^{\circ} \mathrm{S}$. The chl a concentrations from the surface and mesozooplankton in the upper layer $(0$ to $100 \mathrm{~m})$ were analysed from 3992 casts and 1124 hauls respectively. General agreement between chlorophyll concentrations and mesozooplankton biomass distributions was noted on an ocean basin scale. There were non-linear relationships between mean chlorophyll concentration within the 0 to 10 m layer and mesozooplankton biomass within the 0 to $100 \mathrm{~m}$ layer for summed data between December to May and June to November. A comparison of the total biomass of mesozooplankton und phytoplankton, in carbon units, indicated that this ratio varied from 0.15 to 1 in the 0 to $100 \mathrm{~m}$ layer and, on average, the phytoplankton biomass exceeded twice that of mesozooplankton. The seasonal cycles of phyto- and zooplankton biomass for 6 provinces of the tropical zone were qualitatively comparable. Quantitative differences were found in the seasonal amplitudes, which were greater for the regions with nutrient enrichment of the upper layer. Relationships were established between phytoplankton and mesozooplankton biomass for 8 provinces.
\end{abstract}

KEY WORDS: Phytoplankton · Zooplankton $\cdot$ Spatial variability $\cdot$ Atlantic Ocean

\section{INTRODUCTION}

Interactions between physical and biological processes affect the biogeochemical cycling of carbon in the oceans. The basin scale circulation in the Atlantic Ocean incorporates a system of gyres located in the northern and southern hemispheres. North and south of the equator, from 20 to $45^{\circ}$ latitude, anticyclonic gyres occur, which are dominated by downwelling processes. In this scheme, most extended upwelling areas in the Atlantic Ocean occur in zones of subtropical divergences. The Northern Tropical Divergence stretches from $50^{\circ} \mathrm{W}$ to the African coast along $8^{\circ} \mathrm{N}$ latitude in the west and 8 to $15^{\circ} \mathrm{N}$ latitude in the east (Voituriez 1981, Bezrukov 1989). It is weakly developed from the winter to the spring period, but achieves its maximum in the autumn. The Southern Tropical Divergence takes place along latitudes 4 to $5^{\circ} \mathrm{S}$ and

${ }^{*}$ Corresponding author. Email: spiontkovski@notes.cc.sunysb.edu turns eastward at $23^{\circ} \mathrm{W}$ and reaches $15^{\circ} \mathrm{S}$ latitude (Bezrukov 1989, Longhurst 1998).

The northern and southwestern coasts of Africa are believed to have permanent upwelling with high concentrations of nutrients reaching the subsurface layer. These nutrients are not fully utilised by phytoplankton and, with waters of the Canary and Benguela Currents, they are carried south and northwestwards. The regions with high chlorophyll concentration away from the upwelling regions have been remotely sensed by satellites (McClain et al. 1990, Falkowski et al. 1998, Hoepffner et al. 1999). The structural changes in the water masses also influence the major structural-functional characteristics of the plankton communities, which in turn causes differences in biological processes.

Much of our understanding of the biological processes and distribution of the plankton biomass within the tropical Atlantic Ocean has been obtained from 
shipboard observation collected within the framework of international and national projects: METEOR (1925-1927), Equalant I and II (1963-1965), CIPREA (1978-1979), SEQUAL-FOCAL (1983-1985), JGOFS (1989-1990), and World Ocean (national project Former Soviet Union, FSU 1970-1990). On the basis of these numerous measurements, maps were constructed of the plankton distribution (Bogorov et al. 1968, Corcoran \& Manken 1969, Bé et al. 1971, Zernova 1974, Semina 1977, Chromov 1986, Piontkovski \& Ignatyev 1992, Piontkovski et al. 1997, Tseitlin et al. 1997a,b) and also for phytoplankton production (Koblentz-Mishke et al. 1970, Finenko 1978, 1994, Berger 1989). Similarities in the distributions of phytoplankton, primary production and mesozooplankton with the circulation of surface water masses were noted in these studies. Observations of ocean colour from the Coastal Zone Color Scanner (CZCS) satellite showed the macroscale variability (hundreds of $\mathrm{km}$ ) of the near surface chlorophyll-like pigment concentration (NASA 1989). These observations confirmed the role of physics operating in the ocean creating these large-scale geographic and temporal patterns of chlorophyll concentration (McClain et al. 1990, Falkowski et al. 1998).

The relationship between chlorophyll and primary production in the integrated upper layer (Eppley et al. 1985, 1987, Berger 1989, Monger et al. 1997), in the euphotic layer (Lorenzen 1970, Smith 1981, Platt \& Herman 1983) and chlorophyll vertical distribution and primary production (Morel \& Berthon 1989, Hoepffner et al. 1999) was shown for a number of regions. It has been shown from these data that the chlorophyll concentration in the upper layer might be used as an index of changes in water productivity i.e. primary production on a scale of hundreds of $\mathrm{km}$. Changes of primary production on this scale are accompanied by changes of species, plankton community size structure, and biomass ratio between phytoplankton, bacteria, protists, and mesozooplankton. In contrast to upwelling regions, high species diversity and a complex trophic web, which is affected by the size of the phytoplankton cells, can characterize the pelagic communities of oligotrophic waters in the tropical and subtropical regions. Picoplankton $(<1 \mu \mathrm{m})$ and nannophytoplankton (1 to $5 \mu \mathrm{m})$ comprises the major part of phytoplankton biomass (Olson et al. 1990, Li 1995, Buck et al. 1996) and serves as a major food resource for heterotrophic microplankton (Burkill et al. 1993, Harrison et al. 1993, Verity et al. 1993).

Microheterotrophs make up over $50 \%$ of the total metabolism of the heterotrophic part of the community and carbon flux from primary production to zooplankton (Williams 1981, Bender et al. 1992, Fasham et al. 1999, Bode et al. 2001). Mesozooplankton consumes a minor part of phytoplankton primary production (Moralis et al. 1991, Dam et al. 1993, Harrison et al.
1993). However, due to the balance of production processes in the plankton community, mesozooplankton biomass increases with the rise of phytoplankton production and chlorophyll concentration.

The results of continuous measurements of zooplankton abundance and biomass by optical plankton counters in a range from 0.25 to $8.0 \mathrm{~mm}$ have indicated that minimal values are typical for the oligotrophic South Atlantic Subtropical Gyre and oligotrophic Canary Basin along a transect from $49^{\circ} \mathrm{N}$ to $46^{\circ} \mathrm{S}$ (Gallienne \& Robins 1998). Values were 20 times higher in the equatorial region and 10 times higher in the waters near the West African upwelling. Sampling along a transect from $30^{\circ} \mathrm{N}$ to $50^{\circ} \mathrm{S}$ (Galbert \& Agusti 1999) resulted in similar correlated changes of copepod abundance and chlorophyll concentration. This reinforces the known fact that autotrophic and heterotrophic production is more balanced in tropical waters than in higher latitudes.

Vinogradov \& Shushkina (1987), working with the plankton communities of the coastal upwelling regions of Peru, reported the imbalance between primary production and its utilization by heterotrophs. This imbalance results in a weak correlation between phyto- and zooplankton biomass (Gibbons \& Hutchings 1996). Overall, despite the spatial heterogeneity of distributions of the plankton, the observed general tendency is that the biomass of mesozooplankton and other heterotrophs declines with the decline of primary production and phytoplankton biomass.

Micro- and mesozooplankton consume phytoplankton and its production, therefore their distributions in space and time should be linked. However, these links are extremely difficult to verify statistically due to their multiscale spatial-temporal origins (Piontkovski \& Williams 1995). From the point of view of ocean-monitoring of variables by satellite, zooplankton can be considered as a 'filter' impacting, through trophic interactions, on the oceanic phytoplankton and primary production fields (Banse 1994). It is also known that zooplankton plays a significant role in vertical transport of carbon within marine ecosystems, forming the so-called 'biological pump' (Longhurst \& Harrison 1989).

We confined our work to the upper $100 \mathrm{~m}$ layer because in the subtropical and tropical regions, the major part of phyto- and mesozooplankton biomass is concentrated here. Our objectives were to compare the distribution of the chlorophyll concentration with that of the mesozooplankton biomass for the open ocean system and coastal zone, and to examine the relationship between primary production, phytoplankton, and mesozooplankton stocks. In particular, we applied correlation analysis to ascertain whether there are defined co-variation patterns between chl a and mesozooplankton biomass. 


\section{MATERIAL AND METHODS}

Chlorophyll data. Methods: Water samples for chl a and phaeopigments were filtered through membrane filters (effective pore size 0.45 to $0.6 \mu \mathrm{m}$ ) and Whatman GF/F glass-fiber filters (effective pore size $0.7 \mu \mathrm{m}$ ) and pigments were extracted in $90 \%$ acetone. After extraction, chl $a$ and its degradation products were measured using standard fluorometric (Jeffrey et al. 1997) and spectro-photometric (Jeffrey \& Humphrey 1975) methods. Phaeopigment concentration was not used in this work because the fluorometric method often over estimates the concentration of phaeopigments due to the abundant prokaryotes in the tropical waters and presence of chlorophyll $b$ (Neveux \& Lantoine 1993).

Field data: The database contains data from sampling carried out from 1968 to 1992 by national and international programs of the Former Soviet Union (FSU), United Kingdom, France, Canada, Spain, and Germany. The chl a data was obtained from the National Oceanographic Data Center (NODC) (USA) and Banque National de Données Oceanographiques Brest (BNDO) (France) data banks. Chlorophyll measurements from 1435 stations, which were collected during expeditions of the National Ukrainian Academy of Sciences (NUAS), extended these data. Ukrainian data comprised $35 \%$ of NODC and BNDO data sets (Table 1). The total database has 4178 stations with measurements of chl $a$, of which 3992 were selected to extract the $0-10 \mathrm{~m}$ data in the coastal and open ocean regions. The spatial pattern of sampling was irregular (Fig. 1). Station sampling was partially carried out in a form of grids, with a spatial resolution of $20 \mathrm{~km}$ between stations. The winter-spring period was not as well represented as the summer-autumn period, in spite of its importance in the seasonal cycle of the phytoplankton activity. Prior to data analysis, the following editing and data compilation techniques were applied: (1) repeated stations were excluded; (2) stations with obvious mistakes in values of chl a were deleted; (3) stations with measurements carried out by a submersible profiling fluorometer were excluded; (4) data for the stations with diel time series were averaged (i.e. one average value for the whole diel time series was used). In general, our analysis and synthesis of data provides a new data base, which is valuable for the analysis of the meso- and macroscale variability of chl $a$ in the tropical and subtropical regions of the Atlantic Ocean.

Data processing: The edited data were sorted and distributed over the 8 biogeochemical provinces (see Table 3 for names and abbreviations) of the subtropical and tropical Atlantic Ocean (Fig. 1) proposed by Longhurst $(1995,1998)$. Data partitioning was necessary to allow us to estimate chlorophyll concentration and compare the mesozooplankton/chlorophyll relationships over biogeochemical provinces. Two seasonal periods were used in the data analysis: from December to May and from June to November. These periods agree with a flat U-shaped seasonal variation of CZCS surface chlorophyll recently reviewed by Yoder et al. (1993), Banse \& English (1994), and Longhurst (1998) in subtropical and tropical regimes. The distribution of the stations within the geographical provinces for the summer-autumn and winter-spring periods is shown in Fig. 1.

The data set from 1968 to 1992 (4178 stations) was also used to select data to obtain the relationship between the water column chlorophyll concentration $(0$ to $100 \mathrm{~m})$ and the near-surface chlorophyll (0 to $10 \mathrm{~m})$. Analyses were conducted for 1614 vertical profiles, of which approximately $70 \%$ were located in the eastern part of the ocean. This total was made up of 1339 profiles from the deep-sea regions and 275 profiles off the continental shelves. Sampling was carried out to depths of 100 or $150 \mathrm{~m}$, with a vertical resolution of 5 to $25 \mathrm{~m}$. Using the trapezoid rule, chlorophyll concentration in discrete depth intervals was integrated throughout the water column. To approach a normal distribution, logarithmic values of data were used. The following equation was derived: or:

$$
\log \operatorname{chl}_{(\text {tot })}=1.75 \pm 0.16+0.527 \pm 0.01 \log \operatorname{chl}_{(0)}
$$

$$
\operatorname{chl}_{(\text {tot })}=56.2 \operatorname{chl}_{(0)}{ }^{0.527}
$$

for $0.01 \leq \mathrm{chl}_{(0)} \leq 10 \mathrm{mg} \mathrm{m}^{-3} ; 5 \leq \mathrm{chl}_{(\mathrm{tot})} \leq 100 \mathrm{mg} \mathrm{m}^{-2} ; \mathrm{n}=$ $1614 ; \mathrm{r}^{2}=0.62 ; \mathrm{p}<0.001 ; \mathrm{SE}$ (standard error of regression line) $=0.157$, where $\mathrm{chl}_{(0)}$ is concentration of chl $a$ $\left(\mathrm{mg} \mathrm{m}^{-3}\right)$ in the upper layer (0 to $\left.10 \mathrm{~m}\right)$ and $\mathrm{chl}_{(\mathrm{tot})}$ is concentration $\left(\mathrm{mg} \mathrm{m}^{-2}\right)$ in the 0 to $100 \mathrm{~m}$ layer. According to Eq. (1), the measured $\mathrm{chl}_{\text {(tot) }}$ values might differ 2 times from the calculated ones, following $E_{r}=10^{2 \mathrm{SE}}$, where $E_{r}$ is a relative error (Vinogradov et al. 1999).

To estimate phytoplankton biomass in carbon units, the following equation was applied:

$$
B=\operatorname{chl}_{(\text {tot })} \theta
$$

where $B$ is phytoplankton biomass $\left(\mathrm{mg} \mathrm{C} \mathrm{m}^{-2}\right)$ and $\theta$ is the average weighted ratio between organic carbon of phytoplankton and the chlorophyll concentration in the $100 \mathrm{~m}$ layer. Values of $\theta$ were calculated from measurements (Li et al. 1992, 1993, Buck et al. 1996) and modeling of seasonal and vertical changes of $\theta$ over different regions of the Atlantic Ocean (Taylor et al. 1997). In the provinces of the North subtropical gyre (NAST), South Atlantic gyre (SATL), Tropical gyre (NATR), and Western tropical Atlantic (WTRA), $\theta$ was taken as $60 \mathrm{~g} \mathrm{C} \mathrm{g} \mathrm{chl} a^{-1}$, but was $50 \mathrm{~g} \mathrm{C} \mathrm{g} \mathrm{chl} \mathrm{a}^{-1}$ for the provinces ETRA (eastern tropical Atlantic), GUIN (Guinea coastal boundary), and CNRY (eastern coastal boundary) for all seasons. 
Table 1. Sources of data for chlorophyll data base. IBSS = Institute of Biology of the Southern Seas, NASU, Sevastopol, Ukraine (see www.ibss.iuf.net); MHI = Marine Hydrophysical Institute, NASU, Sevastopol, Ukraine (see www.mhi.iuf.net); BNDO = Banque National de Données Oceanographiques, Brest, France (see www.ifremer.fr:582/sismer/sismer/banque_nat_ag. htql); NODC = National Oceanographic Data Center, Silver Spring, Maryland, USA (see www.nodc.noaa.gov/OC5/indwod98. html); BODC/BOFS = British Oceanographic Data Centre/BOFS CD-ROM (see www.bodc.ac.uk/); FOCAL = Programme Francais Ocean et Climat Atlantique Equatorial

\begin{tabular}{|c|c|c|c|c|}
\hline Time period & $\begin{array}{l}\text { Ship and cruise no./ } \\
\text { data set name }\end{array}$ & Region of Atlantic & Source & $\begin{array}{l}\text { Jumber of stations/ } \\
\text { data used }\end{array}$ \\
\hline 1968: May & U7EX & North subtropical & NODC & $6 / 6$ \\
\hline 1971: Jan-Feb & $\mathrm{X} 6$ & Morocco upwelling & NODC & $12 / 12$ \\
\hline 1972: Oct-Nov & PLA & Bay of Biscay & NODC & $7 / 7$ \\
\hline 1973: Apr-May & PH32 & Northeast & NODC & $27 / 27$ \\
\hline 1974: Mar & $\mathrm{CR}$ & Cape Blanc region & NODC & $39 / 39$ \\
\hline 1974: Mar-Apr & $\mathrm{CH}$ & Cape Blanc region & NODC & $78 / 78$ \\
\hline 1974: Mar-May & $\mathrm{AD} 14$ & Cape Blanc region & NODC & $56 / 56$ \\
\hline 1974: Mar-May & $\mathrm{AD} 18$ & Cape Blanc region & NODC & $126 / 126$ \\
\hline 1976: Sep-Oct & GM & Canary Islands region & NODC & $75 / 75$ \\
\hline 1978: Jul-Aug & NZ & Gulf of Guinea & NODC & $51 / 51$ \\
\hline 1978: Aug-Sep & Capricorne, 1 & East equatorial & BNDO & $63 / 62$ \\
\hline 1978: Aug-Sep & $\mathrm{SU}$ & East equatorial & NODC & $59 / 58$ \\
\hline 1979: Feb & SOP1 & East equatorial & NODC & $13 / 13$ \\
\hline 1979: Apr & Capricorne, 2 & East equatorial & BNDO & $29 / 29$ \\
\hline 1979: May & K110 & Central equatorial & NODC & $159 / 158$ \\
\hline 1979: Jun-Jul & Capricorne, 3 & Gulf of Guinea & BNDO & $49 / 48$ \\
\hline 1979: Oct-Nov & Capricorne, 4 & East equatorial & BNDO & $79 / 73$ \\
\hline 1979: Dec-1980: Jan & Vodyanitsky, 7 & Cape Blanc region & IBSS Archives (1980) & $49 / 49$ \\
\hline 1980: Jan & Capricorne, 5 & East equatorial & BNDO, FOCAL 1 & $17 / 16$ \\
\hline 1980: Jan & Lomonosov, 38 & Conakri region & MHI Archives (1980a) & $33 / 25$ \\
\hline 1980: Nov & Lomonosov, 40 & Conakri region & MHI Archives (1980b) & $5 / 5$ \\
\hline 1981: Aug-Sep & $\mathrm{X} 25$ & Portugal coast & NODC & $8 / 8$ \\
\hline 1981: May & $\mathrm{Z}$ & Central subtropical & NODC & $9 / 8$ \\
\hline 1981: Dec-1982: Jan & Vodyanitsky, 11 & South subtropical & IBSS Archives (1982a) & $80 / 80$ \\
\hline 1982: Jul & Capricorne, 6 & Equatorial & BNDO (FOCAL 2) & $45 / 42$ \\
\hline 1982: Jul-Oct & Vodyanitsky, 13 & Tropical and central & IBSS Archives (1982b) & $126 / 117$ \\
\hline 1983: Jan-Feb & Capricorne, 7 & Tropical and equatorial & BNDO (FOCAL 3) & $50 / 48$ \\
\hline 1983: Mar-Apr & $\mathrm{IF}^{1}$ & Cape Blanc region & NODC & $52 / 52$ \\
\hline 1983: Mar-Apr & Meteor, 1 & Cape Blanc region & NODC & $83 / 73$ \\
\hline 1983: Apr & V302 & West subtropical & NODC & $25 / 25$ \\
\hline 1983: Jul-Aug & Capricorne, 8 & Tropical and equatorial & BNDO (FOCAL 4) & $88 / 86$ \\
\hline 1984: Jan-Feb & Capricorne, 9 & Tropical and equatorial & BNDO (FOCAL 5) & $92 / 92$ \\
\hline 1984: Mar & Meteor, 2 & Cape Blanc region & NODC & $17 / 17$ \\
\hline 1984: Apr & Meteor, 3 & Cape Blanc region & NODC & $20 / 20$ \\
\hline 1984: Jul-Aug & Capricorne, 10 & Tropical and equatorial & BNDO & 96/91 \\
\hline 1984: Dec & V449 & West Sargasso Sea & NODC & $7 / 6$ \\
\hline 1985: Jun-Aug & Vernadsky, 32 & West tropical & MHI Archives (1985) & $164 / 164$ \\
\hline 1985: Aug & V520 & West Sargasso Sea & NODC & $4 / 2$ \\
\hline 1985: Nov-Dec & Vodyanitsky, 20 & Tropical & IBSS Archives (1985b) & $29 / 29$ \\
\hline 1986: Jun-Aug & Capricorne, 11 & East tropical & BNDO & $154 / 152$ \\
\hline 1986: Jul & U7DI & East subtropical & NODC & $1 / 1$ \\
\hline 1986: Sep-Oct & Vernadsky, 34 & West tropical & MHI Archives (1986a) & $238 / 238$ \\
\hline 1986: Oct-Dec & Vodyanitsky, 21 & Tropical & IBSS Archives (1986) & $48 / 48$ \\
\hline 1986: Nov & Lomonosov, 47 & East tropical & MHI Archives (1986b) & $281 / 277$ \\
\hline 1987: Jun-Jul & Vernadsky, 36 & West tropical & MHI Archives (1987) & $234 / 234$ \\
\hline 1987: Jun-Jul & Hudson, 1 & Northwest subtropical & BNDO & $16 / 12$ \\
\hline 1987: Jun-Jul & V722 & West Sargasso Sea & NODC & $105 / 102$ \\
\hline 1987: Jul-Oct & Vodyanitsky, 24 & Tropical & IBSS Archives (1987) & $91 / 58$ \\
\hline 1988: Sep & Hudson, 2 & Northwest subtropical & BNDO & $16 / 16$ \\
\hline 1988: Sep & V826 & West Sargasso Sea & NODC & $15 / 15$ \\
\hline 1989: Mar & SE1 & Central subtropical & NODC & $7 / 0$ \\
\hline 1989: Mar-Apr & DR1 & Central subtropical & NODC & $20 / 20$ \\
\hline 1989: Apr & DR2 & East subtropical & NODC & $21 / 12$ \\
\hline 1989: Apr & $\mathrm{SE}$ & Central subtropical & NODC & $23 / 23$ \\
\hline 1989: Apr-May & A2 & North sutropical & NODC & $34 / 30$ \\
\hline 1989: Apr-May & V903 & West tropical & NODC & $29 / 29$ \\
\hline
\end{tabular}


Table 1 (continued)

\begin{tabular}{|llllc|}
\hline Time period & $\begin{array}{l}\text { Ship and cruise no./ } \\
\text { data set name }\end{array}$ & Region of Atlantic & Source & $\begin{array}{c}\text { Number of stations/ } \\
\text { data used }\end{array}$ \\
\hline 1989: May & A3 & North tropical & NODC & $23 / 23$ \\
1989: May & DR3 & East subtropical & NODC & $30 / 30$ \\
1989: May-Jun & DR4 & Northeast tropical & NODC & $20 / 16$ \\
1989: Aug-Sep & N8 & Northeast tropical & NODC & $9 / 8$ \\
1989: Sep-Dec & Vodyanitsky, 29 & Morocco upwelling and & IBSS Archives (1989) \\
& & Gulf of Guinea & & $57 / 41$ \\
1989: Oct-1990: Sep & Sg & West subtropical & NODC & $52 / 52$ \\
1989: Nov-1990: Sep & Sb & West subtropical & NODC & $15 / 15$ \\
1990: Apr & D001 & West subtropical & NODC & $30 / 25$ \\
1990: Apr-May & N9 & East tropical & NODC & $14 / 14$ \\
1990: Apr-Jun & BOFS & NE and Morocco & BODC/BOFS & $334 / 320$ \\
1991: Apr & D101 & West & NODC & $12 / 12$ \\
1991: Apr-May & D17 & Northwest tropical & NODC & $81 / 81$ \\
1992: Sep-Oct & D237 & NW and Morocco & NODC & $62 / 62$ \\
1992: Sep-Oct & Hudson, 3 & NW and Morocco & BNDO & $63 / 53$ \\
1992: Dec & Jean Charcot & Cape Blanc & J. Neveux pers. comm. \\
Total & & & & $16 / 13$ \\
\end{tabular}

Zooplankton data. Methods: The plankton samples were collected by Bogorov-Rass nets and the oceanic model of the Juday nets (80 cm mouth diameter) with mesh sizes of 178 and $200 \mu \mathrm{m}$. All tows were taken in a vertical or oblique manner in the upper 100 to $0 \mathrm{~m}$ and hauled at a speed of approximately $0.5 \mathrm{~m} \mathrm{~s}^{-1}$. Typ- ically, $50 \mathrm{~m}^{3}$ of water was filtered by the net during the collection of each sample. The filtered volume was estimated from the length of the wire out, mouth diameter of the net and duration of tow. The wet weight of samples was obtained either by displacement volume (precision $\pm 0.1 \mathrm{ml}$ ), assuming the specific gravity of
Fig. 1. Chl a measurements in the upper $10 \mathrm{~m}$ layer. Stations from expeditions conducted in summer-autumn (June to November) and winterspring (December to May) periods (1968-1992)

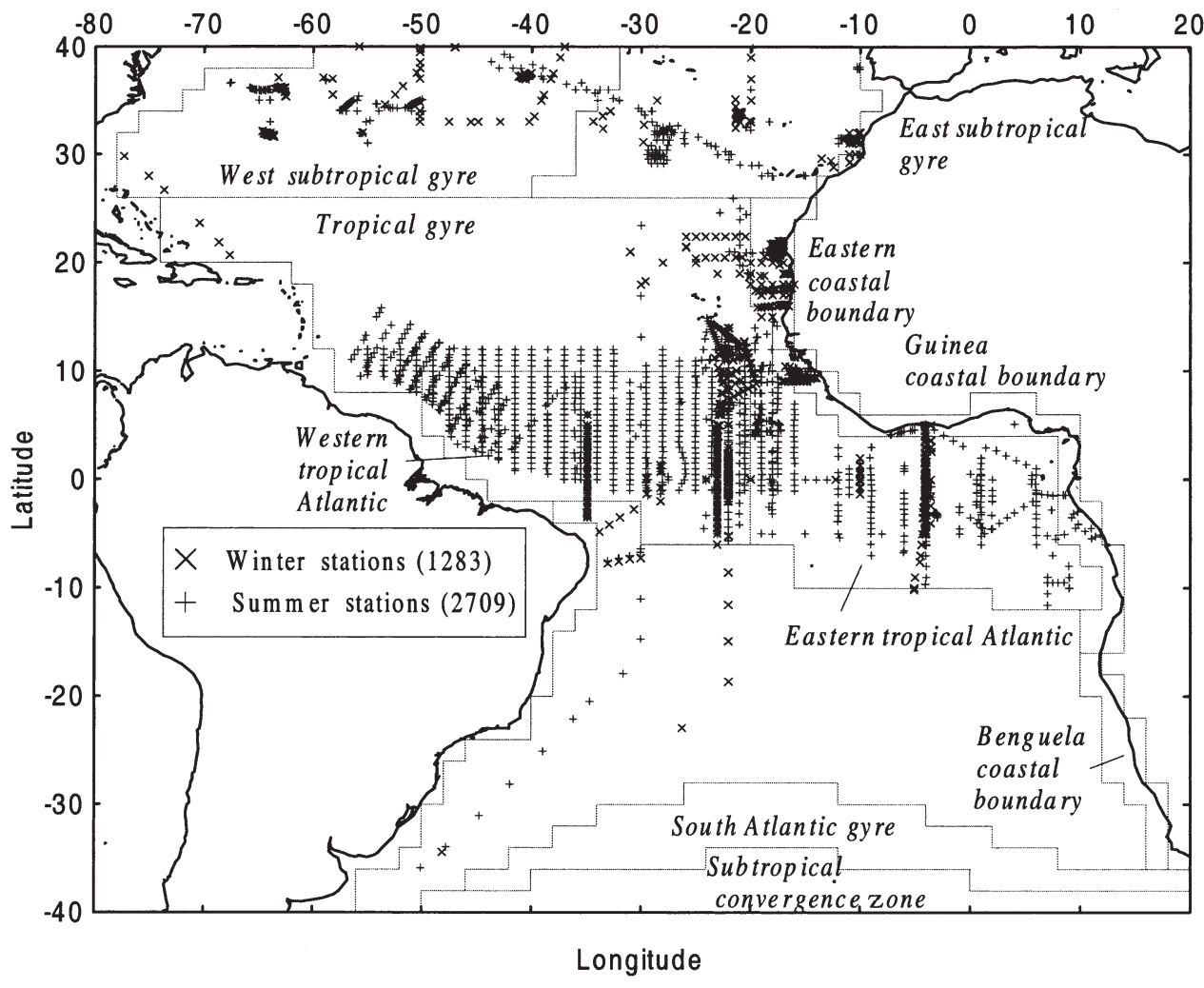




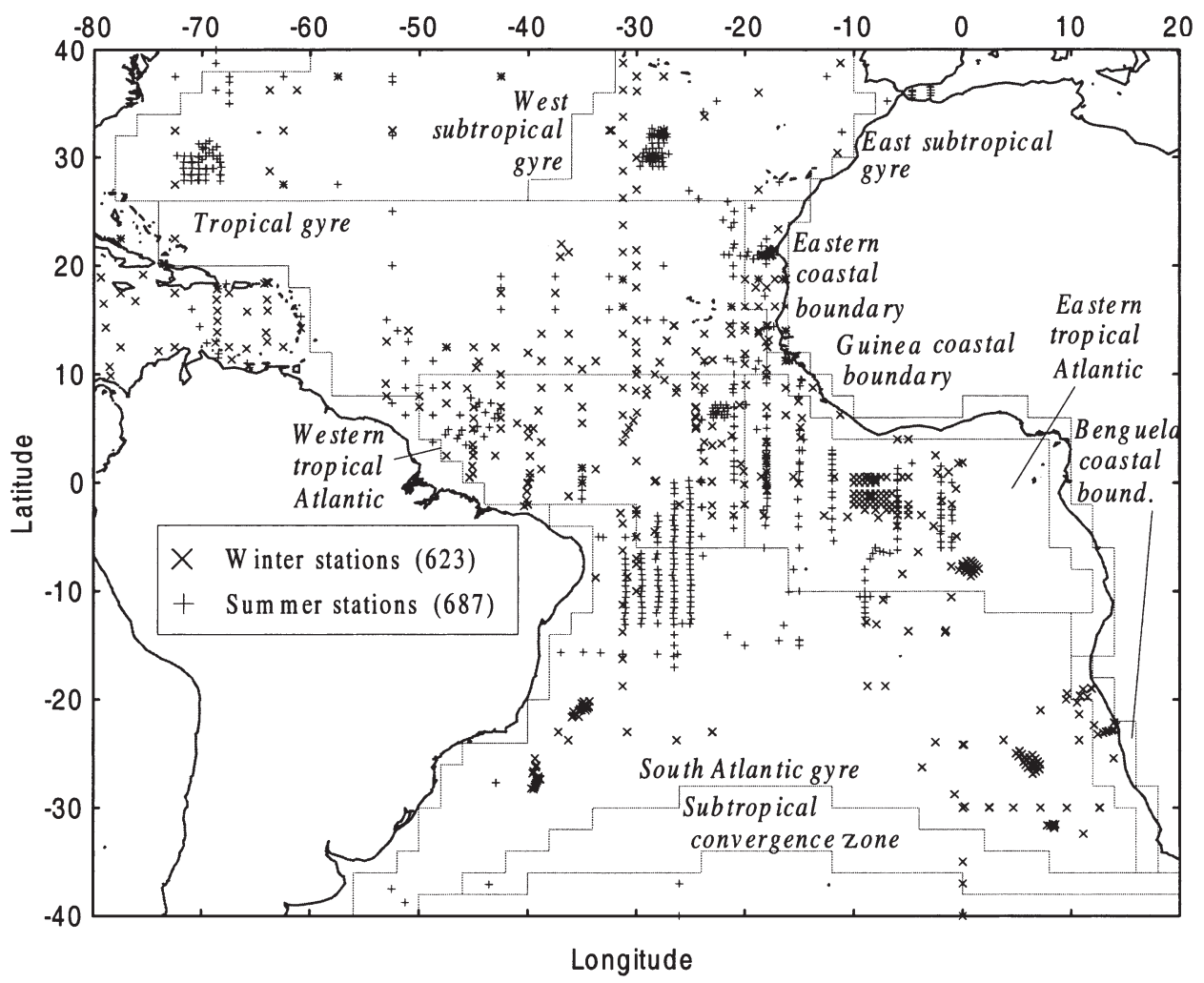

Fig. 2. Mesozooplankton measurements in the upper $100 \mathrm{~m}$. Stations from expeditions of the Former Soviet Union for summer-autumn (June to November) and winter-spring (December to May) periods (1950-1989) seston to be $1 \mathrm{~g} \mathrm{~cm}^{-3}$, or by wet weighing, after blotting, using a balance (precision $\pm 0.1 \mathrm{mg}$ ). Organisms larger than $30 \mathrm{~mm}$ and all jelly fish (medusas, salps, and ctenophores) were removed from the samples before determining the weight or volume. Jelly fish were excluded when determining the weight of the mesozooplankton.

Field data: The data on mesozooplankton biomass at 1310 stations from 40 FSU expeditions to the Atlantic Ocean (1950-1989) were used (Fig. 2, Table 2). These stations were obtained from archives of Marine Hydrophysical Institute (MHI) and Institute of Biology of the Southern Seas (IBSS) and some of them (179) were taken from publications. The network of national programmes and the spatial resolution of sampling was irregular (Fig. 2). Certain stations had fine spatial resolution, ca. 10 s of $\mathrm{km}$, and were performed in station grids. The hauls were taken over many seasons and years and at different times of the day. Prior to data analysis, the following editing and data compilation were applied: (1) stations with obvious mistakes in the values of mesozooplankton biomass were excluded; (2) data for the stations with diel time series were averaged and one average value was used; (3) data were not used when an excessive amount of phytoplankton or detritus was noted in the seston samples.

The number of stations with mesozooplankton following the above analysis was 1124 . The maximum number of stations (745) was in the following 3 provinces: WTRA (230), ETRA (231), and SATL (284). The minimal number of stations was in CNRY (67) and the GUIN (11). The total number of stations for the winter-spring and summer-autumn seasons were almost equal (537 and 587 respectively).

Carbon biomass conversions: Mesozooplankton biovolume was converted to carbon using a factor of $0.05 \mathrm{~g} \mathrm{C} \mathrm{cm}^{-3}$. To convert wet weight $\left(W_{\mathrm{w}}\right)$ into dry weight $\left(W_{\mathrm{d}}\right)$, the formula $W_{\mathrm{w}}=6.25 W_{\mathrm{d}}$ (Vinogradov \& Shushkina 1987) was used. The relationship $W_{\mathrm{c}}=$ $0.31 W_{\mathrm{d}}$ (Wiebe 1988) converted dry mesozooplankton biomass into carbon $\left(W_{\mathrm{c}}\right)$.

Basin-wide maps. Data on chlorophyll concentration (0 to $10 \mathrm{~m}$ ) and mesozooplankton biomass of the upper 0 to $100 \mathrm{~m}$ layer enabled us to reconstruct the spatial distribution on a scale of the whole tropical and subtropical Atlantic Ocean (Figs. 3 \& 4). The Surfer Golden Software (USA) package was applied to design the macroscale field of chlorophyll and mesozooplankton. The Kriging gridding method (Cressie 1991) and smoothing of the grid matrix, with the weight of matrix center $=2$, and the distance- weighting power $=2$, were applied to create the map.

The mean of all measurements at stations over provinces were calculated to estimate chlorophyll in the upper $10 \mathrm{~m}$ and mesozooplankton in the upper $100 \mathrm{~m}$ (Table 3). 
Table 2. Sources of data for mesozooplankton data base

\begin{tabular}{|c|c|c|c|c|}
\hline Time period & Ship and cruise no. & Region of Atlantic & Source & Stn \\
\hline 1950: Jan & Grot, 1 & Guinea coast & Semenova (1961), Chromov (1962) & 5 \\
\hline 1958: Mar-May & Lomonosov, 2 & Central subtropical & Vladimirskaya (1972) & 5 \\
\hline 1958: Nov & Chukovsky, 1 & Guinea coast & Chromov (1965) & 2 \\
\hline 1959: May & Lomonosov, 5 & Meridional section & Kanaeva $(1962,1973)$ & 48 \\
\hline 1959: Aug-Dec & Lomonosov, 6 & Central subtropical & Yashnov (1962) & 46 \\
\hline 1960: Jan-Apr & Lomonosov, 7 & Central subtropical and Cape Blanc & Kanaeva $(1962,1973)$ & 18 \\
\hline 1960: Jul-1961: Jan & Lomonosov, 8 & Central subtropical and Cape Blanc & Kanaeva (1962), Yashnov (1962) & 11 \\
\hline 1961: Mar & Lomonosov, 10 & Guinea coast & Chromov (1965) & 9 \\
\hline 1962: Oct & Lomonosov, 12 & Guinea coast & Chromov (1965) & 4 \\
\hline 1963: Mar-May & Lomonosov, 13 & Central equatorial and Guinea coast & Greze (1971) & 21 \\
\hline 1963: Sep-Oct & Lomonosov, 14 & Central equatorial & Greze (1971), MHI Archives (1963) & 49 \\
\hline 1964: Aug & Ak. Kovalevsky & Cuba coast & Kolesnikov \& Kovaleva (1973) & 2 \\
\hline 1964: Dec-1965: Feb & Lomonosov, 17 & Carribean Sea and Northwest & MHI Archives (1965) & 21 \\
\hline 1964: May & Lomonosov, 15 & West tropical & MHI Archives (1964), Greze (1971) & 27 \\
\hline 1967: Jan-Mar & Kurchatov, 1 & Carribean Sea, Guinea coast & $\begin{array}{r}\text { Lubni-Gercik (1972, 1975), } \\
\text { Kovalevskaya et al. 1968) }\end{array}$ & 12 \\
\hline 1969: Mar & Kurchatov, 3 & West tropical & Lubni-Gercik $(1972,1975)$ & 4 \\
\hline 1969: Dec-1970: Mar & r Lomonosov, 24 & Central and Morocco & Kolesnikov \& Kovaleva (1973) & 13 \\
\hline 1970: Nov-Dec & Vernadsky, 3 & Carribean Sea & MHI Archives (1970) & 30 \\
\hline 1971: Nov & Kurchatov, 11 & South Central & Voronina (1975) & 2 \\
\hline 1972: Apr-May & Lomonosov, 26 & Central equatorial and Benguela & MHI Archives (1972) & 42 \\
\hline 1973: Jan-Mar & Kurchatov, 14 & Carribean Sea & Lubni-Gercik (1975) & 11 \\
\hline 1973: Jan-Mar & Lomonosov, 27 & South subtropical & Greze et al. (1984) & 8 \\
\hline 1974: JanApr & Vernadsky, 8 & Central tropical & MHI Archives74a & 53 \\
\hline 1974: Feb-Apr & Lomonosov, 28 & Central equatorial and Guinea coast & MHI Archives (1974b) & 36 \\
\hline 1974: Nov & Vernadsky, 9 & W Mediterranean & MHI Archives (1974c) & 8 \\
\hline 1976: Jun-Jul & Lomonosov, 30 & South subtropical & Greze et al. (1984) & 9 \\
\hline 1976: Jul & Vernadsky, 13 & Mediterranean & MHI Archives (1976) & 1 \\
\hline 1977: Jun-Aug & Lomonosov, 32 & Central equatorial & Greze et al. (1984) & 112 \\
\hline 1977: Jul-Aug & Vernadsky, 16 & Sargasso Sea & MHI Archives (1977) & 50 \\
\hline 1977: Oct-Nov & Vodyanitsky, 3 & East subtropical & IBSS Archives (1977) & 23 \\
\hline 1978: Feb-Apr & Est.Oktaybr & Easr equatorial & ATLANTNIRO archives (1978) & 48 \\
\hline 1978: Dec-1979: Feb & Vodyanitsky, 5 & Southeast subtropical & IBSS Archives (1979) & 72 \\
\hline 1981: Dec-1982: Jan & Vodyanitsky, 11 & South subtropical & IBSS Archives (1982a) & 98 \\
\hline 1982: Jul-Oct & Vodyanitsky, 13 & Meridional grids & IBSS Archives (1982b) & 142 \\
\hline 1984: Aug & Vernadsky, 28 & West tropical & MHI Archives (1984a) & 17 \\
\hline 1984: Aug-Oct & Vernadsky, 29 & West tropical & MHI Archives (1984b) & 30 \\
\hline 1984: Dec-1985: Feb & Vodyanitsky, 18 & East Equatorial & IBSS Archives (1985a) & 42 \\
\hline 1986: Oct-Nov & Vodyanitsky, 21 & East Equatorial & IBSS Archives (1986) & 46 \\
\hline 1987: Jul-Sep & Vodyanitsky, 24 & East Equatorial & IBSS Archives (1987) & 78 \\
\hline 1989: Oct-Dec & Vodyanitsky, 29 & East Equatorial and Cape Blanc & IBSS Archives (1989) & 55 \\
\hline Total: & & & & 1310 \\
\hline
\end{tabular}

Data sets of chlorophyll-mesozooplankton relationship. To analyse relationships between chlorophyll concentration in the 0 to 10 m layer, and mesozooplankton biomass in the $100 \mathrm{~m}$ layer, the subtropical and tropical Atlantic was partitioned over $3^{\circ} \times 3^{\circ}$ trapeziums and mean parameter values were estimated for each. Trapeziums containing data for only 1 parameter were excluded from the analysis. In the $3^{\circ}$ trapeziums, the average number of measurements was 6 to 20 for chl a and 2 to 8 for mesozooplankton biomass.

\section{RESULTS}

In spite of the sampling carried out during different expeditions, seasons and years, the macroscale pat- terns of chl $a$ and mesozooplankton biomass presented in Figs. 3 \& 4 show similarities in their distributions.

The chl $a$ and zooplankton biomass increased from oceanic to neritic waters. In the central regions of the NAST and SATL gyres, chl a and mesozooplankton biomass levels were low. In the winter-spring season, chl $a$ and zooplankton biomass over the northern and eastern periphery of the subtropical gyre were higher than those observed in the summer-autumn period. Details of patterns of isolines of biomass and their geometry changed over the seasons: the zooplankton distributions through and around the equatorial region were more heterogeneous than those of chl $a$, especially in the summer-autumn season.

The average biomass for the 8 provinces covering the subtropical and tropical zones allowed a compari- 
Table 3. Average chl a concentration and range for surface layer (0 to $10 \mathrm{~m}, \mathrm{mg} \mathrm{m}^{-3}$ ) and mesozooplankton (MZ) biomass in wet weight in the upper $100 \mathrm{~m}$ layer $\left(\mathrm{mg} \mathrm{m}^{-3}\right)$. In brackets: minimal and maximal values; $\mathrm{n}$ : number of measurements; Ave: mean; SD: Standard deviation

\begin{tabular}{|c|c|c|c|c|c|c|c|}
\hline \multirow[t]{2}{*}{ Province } & \multirow[b]{2}{*}{$\mathrm{n}$} & \multirow{2}{*}{$\begin{array}{l}\text { Chl a } \\
\text { Avg. }\end{array}$} & \multirow[b]{2}{*}{$\mathrm{SD}$} & \multicolumn{3}{|c|}{ - Mesozooplankton } & \multirow{2}{*}{$\begin{array}{c}\mathrm{Chl} \mathrm{a/MZ} \\
\times 10^{-3}\end{array}$} \\
\hline & & & & $\mathrm{n}$ & Avg. & SD & \\
\hline \multicolumn{8}{|l|}{ Summer-autumn (June to November) } \\
\hline East subtropical gyre (NAST, E) & 168 & $\begin{array}{c}0.37 \\
(0.01-3.17)\end{array}$ & 0.62 & 75 & $\begin{array}{c}24 \\
(21-80)\end{array}$ & 13 & 15.0 \\
\hline West subtropical gyre (NAST, W) & 182 & $\begin{array}{c}0.10 \\
(0.03-0.43)\end{array}$ & 0.05 & 68 & $\begin{array}{c}70 \\
(18-250)\end{array}$ & 44 & 1.4 \\
\hline Tropical gyre (NATR) & 527 & $\begin{array}{c}0.14 \\
(0.01-0.73)\end{array}$ & 0.10 & 56 & $\begin{array}{c}110 \\
(3-1000)\end{array}$ & 154 & 1.2 \\
\hline Western tropical Atlantic (WTRA) & 962 & $\begin{array}{c}0.16 \\
(0.01-3.93)\end{array}$ & 0.18 & 124 & $\begin{array}{c}113 \\
(8-800)\end{array}$ & 111 & 1.4 \\
\hline Eastern tropical Atlantic (ETRA) & 757 & $\begin{array}{c}0.29 \\
(0.01-3.56)\end{array}$ & 0.24 & 115 & $\begin{array}{c}132 \\
(67-450)\end{array}$ & 66 & 2.2 \\
\hline South Atlantic gyre (SATL) & 31 & $\begin{array}{c}0.09 \\
(0.02-0.19)\end{array}$ & 0.04 & 118 & $\begin{array}{c}79 \\
(15-411)\end{array}$ & 62 & 1.1 \\
\hline Eastern coastal boundary (CNRY) & 17 & $\begin{array}{c}0.87 \\
(0.17-3.75)\end{array}$ & 0.86 & 27 & $\begin{array}{c}162 \\
(3-700)\end{array}$ & 178 & 5.3 \\
\hline Guinea coastal boundary (GUIN) & 65 & $\begin{array}{c}0.76 \\
(0.10-4.57)\end{array}$ & 0.88 & 4 & $\begin{array}{c}399 \\
(27-1000)\end{array}$ & 419 & 1.9 \\
\hline Sub-total: & 2709 & & & 587 & & & \\
\hline \multicolumn{8}{|l|}{ Winter-spring (December to May) } \\
\hline East subtropical gyre (NAST, E) & 111 & $\begin{array}{c}0.44 \\
(0.04-2.64)\end{array}$ & 0.37 & 25 & $\begin{array}{c}81 \\
(49-120)\end{array}$ & 24 & 5.4 \\
\hline West subtropical gyre (NAST, W) & 154 & $\begin{array}{c}0.35 \\
(0.04-2.06)\end{array}$ & 0.34 & 15 & $\begin{array}{c}88 \\
(50-250)\end{array}$ & 48 & 3.9 \\
\hline Tropical gyre (NATR) & 76 & $\begin{array}{c}0.18 \\
(0.03-0.885)\end{array}$ & 0.17 & 75 & $\begin{array}{c}379 \\
(20-3000)\end{array}$ & 461 & 0.5 \\
\hline Western tropical Atlantic (WTRA) & 303 & $\begin{array}{c}0.11 \\
(0.01-0.33)\end{array}$ & 0.05 & 96 & $\begin{array}{c}212 \\
(27-1060)\end{array}$ & 202 & 0.5 \\
\hline Eastern tropical Atlantic (ETRA) & 128 & $\begin{array}{c}0.15 \\
(0.06-0.67)\end{array}$ & 0.10 & 116 & $\begin{array}{c}240 \\
(40-1000)\end{array}$ & 177 & 0.6 \\
\hline South Atlantic gyre (SATL) & 39 & $\begin{array}{c}0.08 \\
(0.02-0.50)\end{array}$ & 0.09 & 163 & $\begin{array}{c}73 \\
(3-1088)\end{array}$ & 121 & 1.1 \\
\hline Eastern coastal boundary (CNRY) & 441 & $\begin{array}{c}3.75 \\
(0.03-21.75)\end{array}$ & 3.12 & 40 & $\begin{array}{c}818 \\
(6.5-3000)\end{array}$ & 820 & 4.6 \\
\hline Guinea coastal boundary (GUIN) & 23 & $\begin{array}{c}0.74 \\
(0.10-3.58)\end{array}$ & 0.58 & 7 & $\begin{array}{c}1247 \\
(530-3000)\end{array}$ & 830 & 0.6 \\
\hline Sub-total: & 1283 & & & 537 & & & \\
\hline
\end{tabular}

son of the productivity and chlorophyll:mesozooplankton ratios over the regions (Table 3). The biogeochemical provinces differed in their average values of chl a and mesozooplankton biomass. At the same time, the coefficients of variation are fairly similar and high. On average, values of the chlorophyll and mesozooplankton in the oceanic provinces differ by 4 to 5 times, while this difference is 1 order of magnitude between oceanic and neritic provinces. High chl a values were observed in the NAST, especially in its eastern part (near upwelling off Morocco and Portugal) in the summer-autumn period (Fig. 2). There, chl a values were 0.5 to $1.0 \mathrm{mg} \mathrm{m}^{-3}$ but they did not exceed $0.1 \mathrm{mg} \mathrm{m}^{-3}$ in the central part of the gyre. In the NAST (E), zooplankton biomass was low with values of 24 to $82 \mathrm{mg} \mathrm{m}^{-3}$ against a background of high annual chl a biomass (Table 3). There was a similar zooplankton average biomass in the SATL and WTRA, but the chl a values were 3 times lower in the SATL gyre. In the provinces of the WTRA and NATR gyres, chl a was 0.14 to $0.18 \mathrm{mg} \mathrm{m}^{-3}$, while the mesozooplankton biomass differed several times and was higher than in the NAST province.

The chlorophyll:zooplankton biomass ratio was not stable throughout the year (except in the SATL province). In the summer-autumn, this ratio was 2 times higher than in the winter-spring period. In the 5 provinces (NAST [E], NATR, WTRA, ETRA, and GUIN), a 2.5 to 4 times increase in the ratio was noted from the winter-spring to summer-autumn periods. 
However, this ratio was higher in the summer-autumn period in NAST (W) and it was permanently high in the SATL throughout the year. The maximum ratio was observed in the NAST (E) and its adjacent neritic province (CNRY) for both periods. In the other oceanic provinces, ratios were 5 to 10 times lower; i.e. there was more mesozooplankton biomass per phytoplankton biomass in these provinces.

If data on chl $a$ and zooplankton are averaged within the provinces and these averaged values are compared, no correlation is observed between chl $a$ and zooplankton on a basin-wide scale.

To analyse mesozooplankton-chl a relationships in detail, average values of both parameters were calculated for $3^{\circ} \times 3^{\circ}$ trapeziums. The positions of the graph

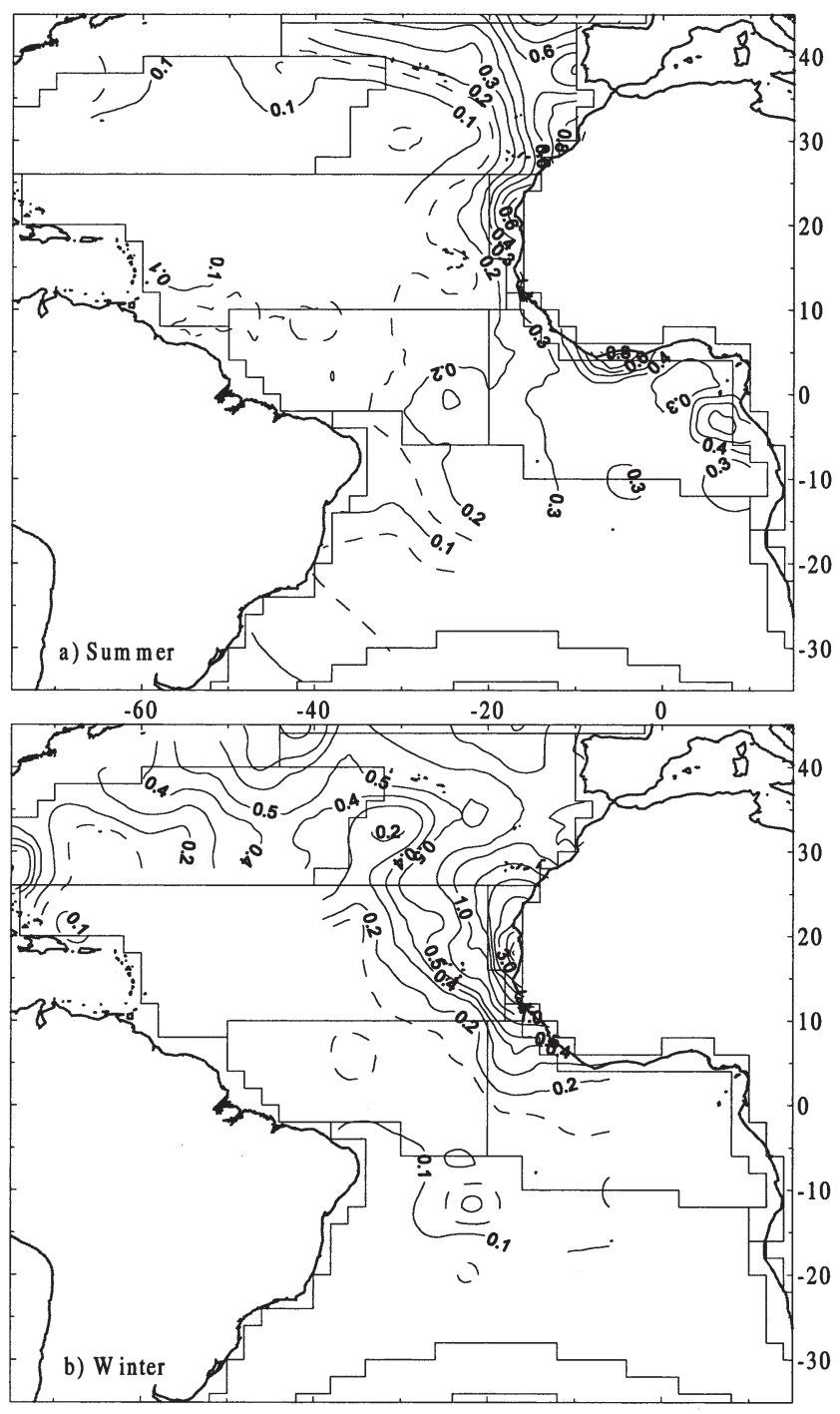

Fig. 3. Spatial distribution of $\operatorname{chl} a\left(\mathrm{mg} \mathrm{m}^{-3}, 0\right.$ to $\left.10 \mathrm{~m}\right)$ for (a) summer-autumn (June to November) and (b) winter-spring (December to May)
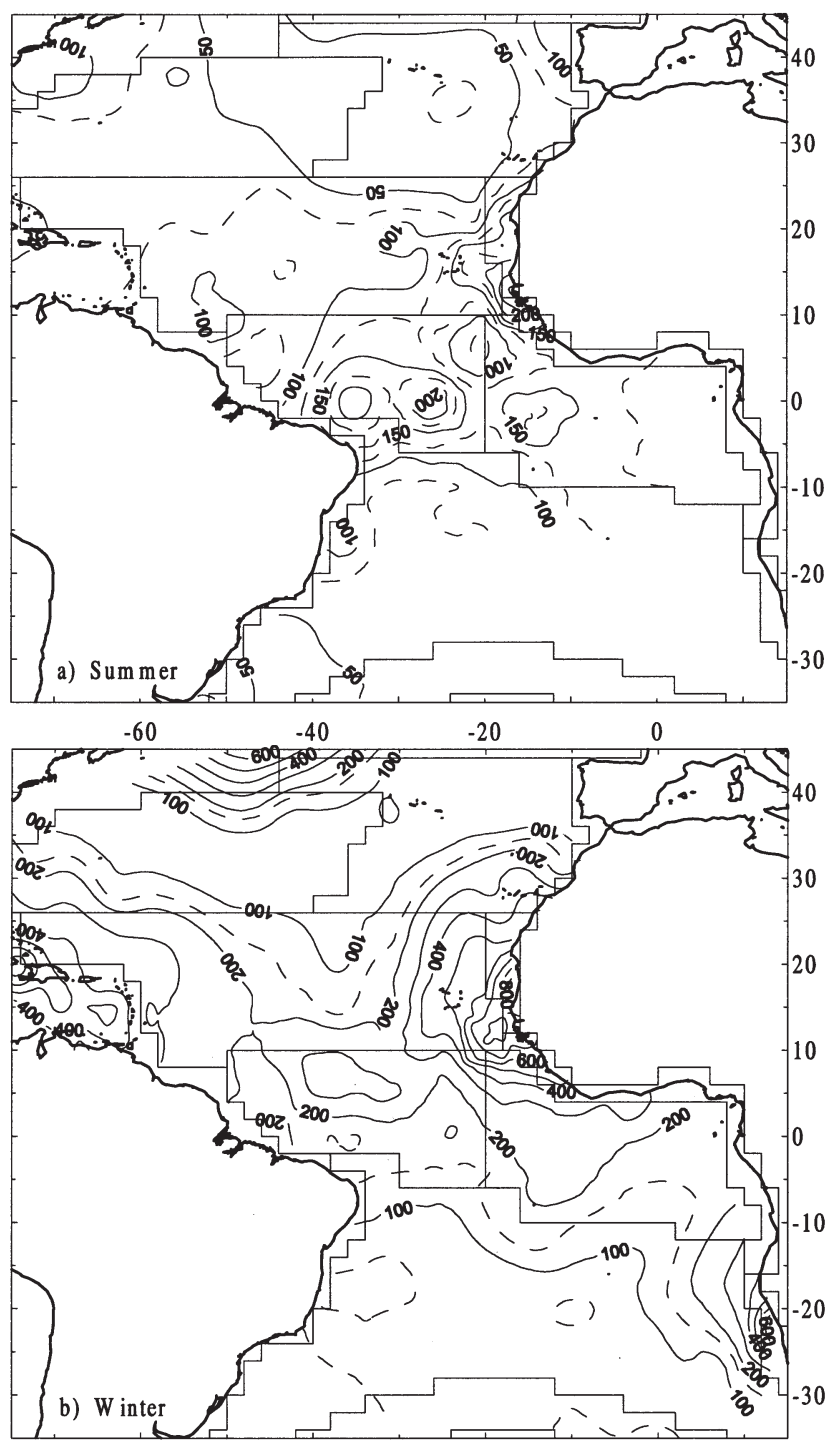

Fig. 4. Spatial distribution of mesozooplankton biomass (mg $\mathrm{m}^{-3}, 0$ to $100 \mathrm{~m}$, wet weight) for (a) summer-autumn (June to November) and (b) winter-spring (December to May) periods

points have an elliptical type trajectory for both periods (Fig. $5 b, f$ ). In a range of chl a from 0.2 to $1.0 \mathrm{mg} \mathrm{m}^{-3}$, different zooplankton biomass values correspond to the same chl a concentration. Several reasons can be put forward to explain this pattern. First, the pattern obtained is a random one due to correspondence of data to various seasons and years. Second, mesozooplankton-chl a relationships can change over regions and depend upon a number of trophic levels. Third, the pattern observed is due to biotic interactions (like the 'predator-prey' system), where the increase of phyto- and mesozooplankton biomass takes place with a time lag (as is known for polar and temperate regions). 

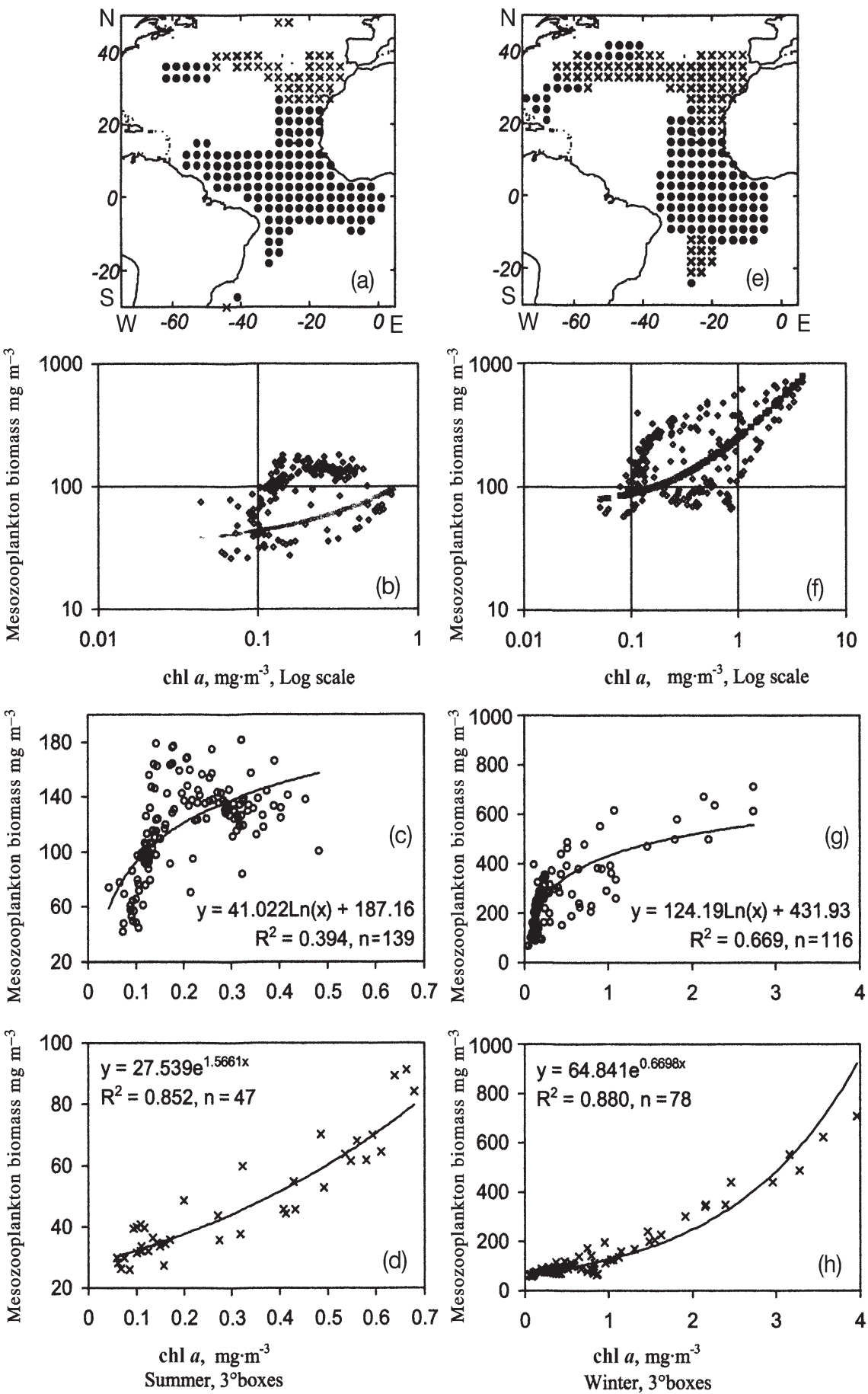

Fig. 5. Relationships between average mesozooplankton biomass $\left(\mathrm{mg} \mathrm{m}^{-3}\right.$; 0-100 $\mathrm{m}$ ) and chl a concentration $\left(\mathrm{mg} \mathrm{m}^{-3}, 0\right.$ to $10 \mathrm{~m}$ ) in the subtropical and tropical Atlantic Ocean for $3^{\circ} \times 3^{\circ}$ grids, for June to November and December to May: (a) and (e): distribution of stations with low $(\mathbf{x})$ and high $(\bullet)$ mesozooplankton:chl a ratios, for summer-autumn and winter-spring, respectively; (b) and (f): changes of mesozooplankton biomass in relation to chl a concentration for summer-autumn and winter-spring, respectively; (c) and (g): relations between mesozooplankton biomass and chl a concentration in provinces of the NATR, WTRA, ETRA, and GUIN for summer-autumn and winter-spring, respectively; (d) and (h): relationship between mesozooplankton and chl a concentration in provinces of the NAST, SATL, and CNRY for summer-autumn and winter-spring, respectively
To test these hypotheses, the whole data set (Fig. 5b) was partitioned into the upper and lower parts along the major axis of the ellipse. The lower part of the data set could be mostly attributed to the SATL, NAST and its adjacent neritic province (Fig. 5a,e). The upper part of the data came from the 5 other provinces covering the tropical zone. When the data were averaged in $1^{\circ} \times 1^{\circ}$ trapeziums, the pattern observed in the mesozooplankton-chl $a$ relationship was still the same as the $3^{\circ}$ trapeziums and the data (from the upper and low parts of the ellipse in Fig. 6b) did not change their positions (Figs. 5a \& 6a) and curved shape (Figs. 6c,d). Thus, we conclude that the observed pattern in the mesozooplankton-chl a relationships is not a random one. Mesozooplankton biomass was positively related to the chlorophyll concentration. The coefficient of determination was in the range from 0.39 to 0.88 with an average of 0.7 (Fig. 5c,d,g,h). Low coefficient values were obtained for the summer-autumn period (Fig. 5c). Possibly, the parabolic relationship we used is not an optimal way to parameterise this link. For instance, the third order polynomial $(y=$ $\left.9085 x^{3}-8388 x^{2}+2457 x-91\right)$ increased $\mathrm{r}^{2}$ to 0.6 for data in Fig. 5c. Although $\mathrm{r}^{2}$ increased 1.5 times, the results obtained using these 2 algorithms only differed by $13 \%$. Therefore we decided to use the parabolic approximation.

In the SATL, NAST and its adjacent neritic province (CNRY), mesozooplankton biomass increased exponentially to chl a concentration. (Fig. 5c,g). This relationship held in the range of chl $a$ to $0.7 \mathrm{mg} \mathrm{m}^{-3}$ in summer and to $4.0 \mathrm{mg} \mathrm{m}^{-3}$ in the winter period. The slope of the curve changes from 0.67 in the winter-spring period to 1.57 in the summer and autumn. The growth of zooplankton biomass with the increase of chlorophyll concentration was lower in the tropical provinces (NATR, WTRA, and ETRA), which had narrow and numerous zones of local upwelling and downwelling (Fig. 5c,g). The one order of magnitude increase of chl $a$, from 0.3 to $3.0 \mathrm{mg} \mathrm{m}^{-3}$, was only 

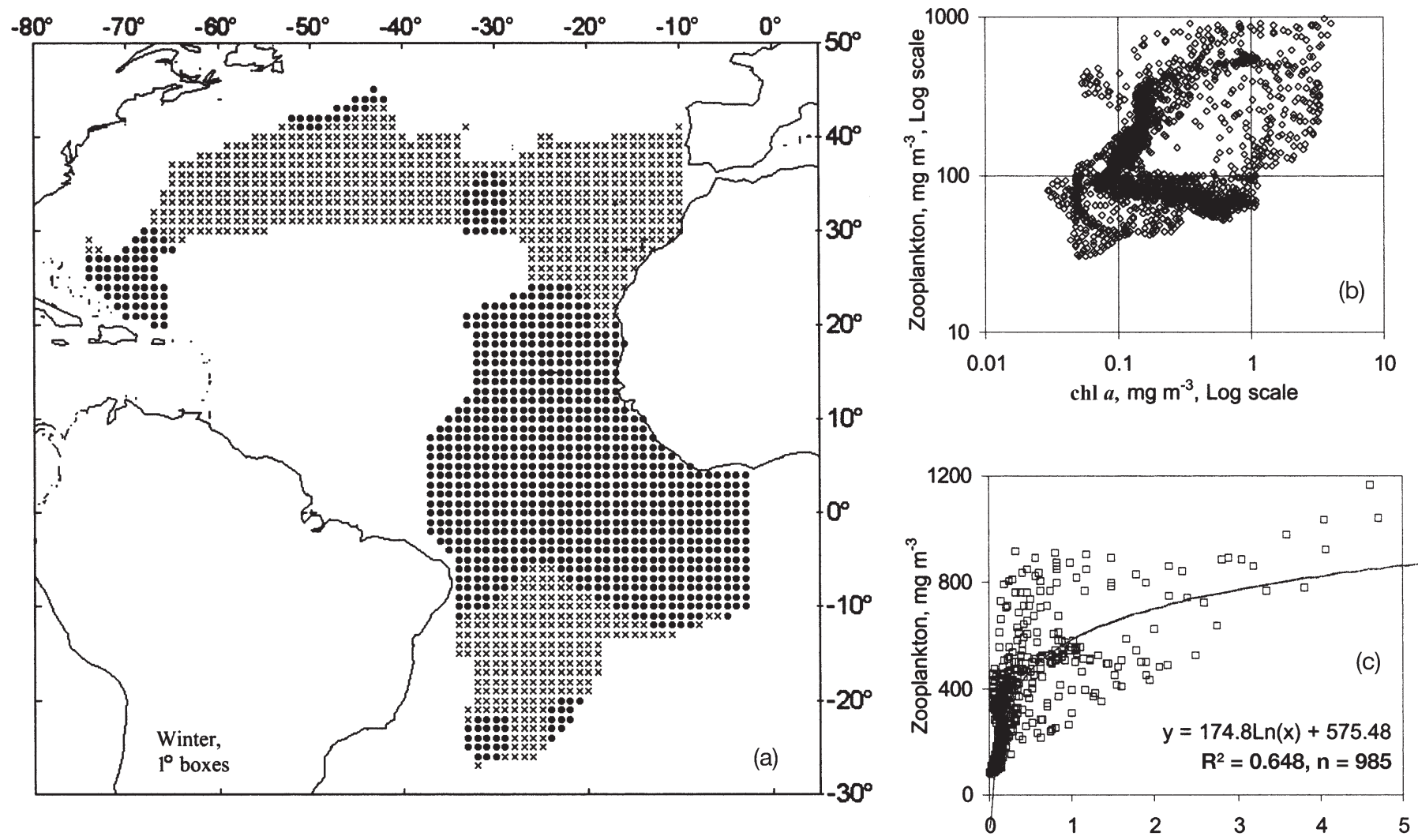

Fig. 6. Relationship between average mesozooplankton biomass $\left(\mathrm{mg} \mathrm{m}^{-3}, 0\right.$ to $\left.100 \mathrm{~m}\right)$ and chl a concentration $\left(\mathrm{mg} \mathrm{m}^{-3}, 0\right.$ to $10 \mathrm{~m}$ ) for $1^{\circ} \times 1^{\circ}$ grid in the subtropical and tropical Atlantic Ocean in winter-spring period: (a) distribution of stations with low (x) and high ( $\bullet$ mesozooplankton:chl a ratio; (b) relation of mesozooplankton biomass to chl a concentration. (c) relationship between mesozooplankton biomass and chl a concentration in provinces NATR, WTRA, ETRA, and GUIN (a) relationship between mesozooplankton and chl a concentration in provinces of NAST, SATL, and CNRY

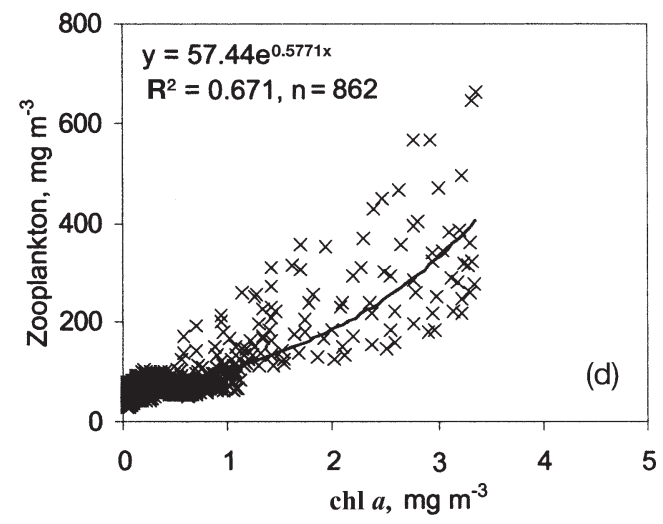

accompanied by a doubling of mesozooplanktonchlorophyll relationships (Fig. $5 \mathrm{c}-\mathrm{h}$ ) and the average chl a concentration in each province (Table 3) mesozooplankton biomass in these regions (Fig. 5g). The mesozooplankton-chlorophyll relationships (Fig. 5c-h) and the average chl a concentration in each province (Table 3) was used to calculate the mesozooplankton biomass. These calculated values were in fairly good agreement with the observed values in Table 3 , with $\mathrm{r}^{2}=$ 0.73. Distinct differences between calculated and observed values were observed for some of the coastal provinces, where the average mesozooplankton biomass was obtained from a low number of measurements (4 to 7 stations).

In order to compare the phyto- and zooplankton biomass for the 0 to $100 \mathrm{~m}$ layer in carbon units, we used average chl $a$ in the 0 to $10 \mathrm{~m}$ layer (data for $3^{\circ}$ $\times 3^{\circ}$ ), ratio (1) and coefficients transferring chl $a$ and wet zooplankton biomass into organic carbon (see 'Materials and methods'). The shapes of the relationships of the mesozooplankton and phytoplankton for the $100 \mathrm{~m}$ layer in carbon units per $\mathrm{m}^{-2}$ are similar to 
those in Fig. 5. The mesozooplankton carbon in the NAST and SATL provinces for data between June and November can be characterized by the following relationships:

$$
\text { Ln } B_{\mathrm{MZ}}=\operatorname{Ln} 0.09+0.56 B_{\mathrm{P}}
$$

for $0.5 \leq B_{\mathrm{P}} \leq 5 ; \mathrm{r}^{2}=0.82, \mathrm{p}<0.001, \mathrm{n}=40$

Between December and May:

$$
\text { Ln } B_{\mathrm{MZ}}=\operatorname{Ln} 0.20+0.37 B_{\mathrm{P}}
$$

for $0.5 \leq B_{\mathrm{P}} \leq 5 ; \mathrm{r}^{2}=0.84, \mathrm{p}<0.001, \mathrm{n}=77$

where $B_{\mathrm{MZ}}$ and $B_{\mathrm{P}}$ are mesozooplankton and phytoplankton carbon, $\mathrm{gC} \mathrm{m}^{-2}$, respectively.

For the other provinces between June and November:

$$
B_{\mathrm{MZ}}=0.39 \operatorname{Ln}\left(B_{\mathrm{P}}\right)+0.46
$$

for $0.5 \leq B_{\mathrm{P}} \leq 3 ; \mathrm{r}^{2}=0.4, \mathrm{p}<0.01, \mathrm{n}=139$

Between December and May:

$$
B_{\mathrm{MZ}}=1.17 \operatorname{Ln}\left(B_{\mathrm{P}}\right)+0.72
$$

for $0.5 \leq B_{\mathrm{P}} \leq 3 ; \mathrm{r}^{2}=0.67, \mathrm{p}<0.001, \mathrm{n}=116$

Eqs. (4) to (6) lead to the conclusion that the $B_{\mathrm{Mz}}: B_{\mathrm{p}}$ ratio declines with an increasing phytoplankton biomass. This refers to the NAST and SALT provinces where the $B_{\mathrm{Mz}}: B_{\mathrm{P}}$ ratio declines from 0.2 to 0.1 from June to November and from 0.5 to 0.2 from December to May. In the other provinces, in summer and autumn the $B_{\mathrm{Mz}}: B_{\mathrm{P}}$ ratio equals 0.5 at a low level of phytoplankton biomass $\left(1 \mathrm{gC} \mathrm{m}^{-2}\right)$, and 0.3 at a high level of phytoplankton biomass $\left(3 \mathrm{gC} \mathrm{m}^{-2}\right)$. In the winter and spring seasons, this ratio increases 1.5 times and varies in the range of 0.4 to 0.8 . Thus, in the subequatorial and tropical regions, mesozooplankton biomass is half that of phytoplankton. The lowest $B_{\mathrm{Mz}}: B_{\mathrm{p}}$ ratios were in the NAST and SALT provinces, where values were the half those measured in the other provinces.

\section{DISCUSSION}

\section{Chlorophyll a}

Remote sensing of the ocean colour has enabled the estimation for the first time, on a global scale, of the spatial-temporal changes of chlorophyll concentrations in the upper layer of the ocean. The analysis of these data has shown that chlorophyll changes do correlate with oceanic circulation and physical processes favouring the nutrient flux into the photosynthesis zone (Falkowski et al. 1998). In the central oceanic gyres (spanning NAST and SALT), where nutrient flux is low and chlorophyll concentration is $<0.2 \mathrm{mg}$ $\mathrm{m}^{-3}$, the oligotrophic area shrinks from summer to winter in both hemispheres, between $40^{\circ} \mathrm{N}$ and $40^{\circ} \mathrm{S}$, according to CZCS images (Falkowski et al. 1998). The map of chlorophyll concentration derived herein from direct sampling is less detailed than the CZCS maps. However, contours of regions with a significant chlorophyll concentration corroborate qualitatively. In both maps (i.e. in the CZCS and Fig. 3), high values were observed in coastal upwelling regions, whereas the lowest ones were in the central oceanic gyres. From the map based on direct sampling (Fig. 3), the area with low chlorophyll is wider in the northern summer than in winter. From June to November, chlorophyll values in NAST (W), NATR, WTRA, ETRA and SALT were averaged from 1968 through 1992 (Table 3). The CZCS data averaged from 1978 through 1986 (Longhurst 1995) were different by only $0.01 \mathrm{mg} \mathrm{m}^{-3}$. In the coastal provinces (CNRY and GUN), the CZCS data were $20 \%$ higher. In December through May, differences between satellite and direct field measurements were higher, but they were in a range of $\pm 30 \%$. This low variability enables us to assume that climatic variability of chlorophyll is relatively low.

\section{Mesozooplankton}

We have compared our sampled data on mesozooplankton biomass (Fig. 4) with the map of zooplankton biomass published by Tseitlin et al. (1997b), who used annually averaged values. Tseitlin et al. (1997b) used data from different mesh sizes and depths sampled in the 0 to $500 \mathrm{~m}$ layer and calculated the values for the 0 to $100 \mathrm{~m}$ layer; he only used 9 of the 40 cruises given in Table 2. We restricted ourselves to the data primarily collected at night using the same nets covering the 0 to 100 m layer. In both maps, elevated values were observed outside the coastal upwelling off Africa, where the upwelling zones tend to span 50 to $100 \mathrm{~km}$ coastal zones. Elevated biomass values can cover several hundred $\mathrm{km}$ in these coastal zones (Cushing 1975). The lowest values were in the NAST and SATL provinces. According to our map, annual biomass was in the range of 65 to $75 \mathrm{mg} \mathrm{m}^{-3}$. Tseitlin et al. (1997b) reported values from 25 to $100 \mathrm{mg} \mathrm{m}^{-3}$ for the same regions. The most distinct differences noted were for the central SATL where Tseitlin et al. had values $<25 \mathrm{mg} \mathrm{m}^{-3}$. They emphasized, however, that due to the lack of measurement between $20^{\circ}$ and $40^{\circ} \mathrm{S}$, these values should be taken with caution.

Using concentrations of chlorophyll and mesozooplankton converted into carbon we determined that the mesozooplankton:phytoplankton ratio varied from 0.15 to 1.0 in subtropical and tropical regions. Low ratios are typical for NAST and SALT with the aver- 
age values of 0.15 and 0.23 for summer and winter seasons respectively. These values were 2.5 to 3 times higher in the other provinces. In general, the amount of mesozooplankton carbon per unit of phytoplankton carbon is less in low-productive regions, in comparison with the moderate productive ones. One of the reasons is the difference in the phytoplankton consumption rate by mesozooplankton due to variance in its abundance and size structure. For instance, consumption of phytoplankton by copepods was studied by Huskin et al. $(2001 \mathrm{a}, \mathrm{b})$ in spring and autumn along the latitudinal transect from $50^{\circ} \mathrm{N}$ to $50^{\circ} \mathrm{S}$. The rate measured by the chlorophyll content in copepod stomachs reached $150 \mathrm{mg} \mathrm{C} \mathrm{m}^{-2} \mathrm{~d}^{-1}$ in the upwelling region in the BENG province. At the equator (WTRA and ETRA), where zones of intensive or low upwelling were associated with the divergence, the rate was 44 to $77 \mathrm{mgC} \mathrm{m}^{-2} \mathrm{~d}^{-1}$. In the regions with stable water mass structure (i.e. NAST and SATL) the rate was 9 to 12 and 17 to $34 \mathrm{mgC} \mathrm{m}^{-2} \mathrm{~d}^{-1}$ respectively, which, in terms of daily grazing, removes 3 to $29 \%$ of primary production. Quantitative assessments of mesozooplankton grazing in regard to primary production rates were reported for various coastal and oceanic ecosystems by Calbert (2001), who showed that in a wide range (from 28 to $4000 \mathrm{mgC} \mathrm{m}^{-2} \mathrm{~d}^{-1}$ ), the ingestion rate and the intensity of feeding (i.e. grazing rate normalized by mesozooplankton biomass in carbon units per day) could be represented by a parabolic equation with a degree of 0.64 and 0.53 respectively. In low-productive communities, where primary production is in the region of 0.05 to $0.25 \mathrm{gC}$ $\mathrm{m}^{-2} \mathrm{~d}^{-1}$, algae contribute 3 to $7 \%$ of the daily biomass diet of mesozooplankton in carbon units. In the communities with moderate productivity $(0.25$ to $1.0 \mathrm{~g} \mathrm{C}$ $\mathrm{m}^{-2} \mathrm{~d}^{-1}$ ) this contribution was 7 to $15 \%$, whereas in the productive communities it was 15 to $30 \%$ (Calbert 2001, Fig. 2). Estimates of phytoplankton consumption by copepods in oligotrophic subtropical waters near to the Azores indicated that, depending on season, phytoplankton contributes 4 to $12 \%$ ( $8 \%$ average) of copepod carbon biomass (Huskin et al. 2001b). For a metabolism of $60 \%$ as the level of food assimilation, the minimal food requirements of copepods with a wet weight of $5 \times 10^{-4}$ to $5 \times 10^{-5} \mathrm{~g}$ should be 20 to $40 \%$ of their body mass (Sushchenya 1975). Thus it seems obvious that copepods are unable to cover energy expenditures at the ingestion rates observed in the oligotrophic regions of the tropical and subtropical Atlantic. They can only supplement this energy requirement if they act as predators. On the other hand, when primary production changes from 0.05 to $1.0 \mathrm{gC} \mathrm{m}^{-2} \mathrm{~d}^{-1}$, the phytoplankton contribution to the daily diet of mesozooplankton can increase approximately 5 times. Therefore, in the moderate productive regions the amount of mesozooplankton carbon biomass per unit of phytoplankton carbon would be higher than in oligotrophic regions. Suggested reasons for these discrepancies are that in oligotrophic regions the length of the trophic chains are extended and mesozooplankton (copepods) only take 3 to $7 \%$ of available phytoplankton, while in productive regions, where the trophic chain is short, this consumption reaches 15 to $30 \%$.

Gasol et al. (1997) summarised the available data to estimate the pyramid of biomass (organic carbon) from 10 well-studied open ocean communities of the Atlantic, Pacific, Indian, and Mediterranean Sea, from the northern arctic to the southern subtropical latitudes. The authors concluded that the mesozooplankton:phytoplankton ratio declines with an increase of phytoplankton biomass, and the average value of this ratio is about 0.5 in the plankton of low productive regions (Gasol et al. 1997, their Fig. 4). The ratio (in organic carbon) range was from 0.15 to 0.70 in the upper $200 \mathrm{~m}$ layer in the Indian Ocean (Tranter 1973), which is similar to that in the Atlantic Ocean.

Measurements carried out at a geographically fixed station in the Arabian Sea $\left(21^{\circ} \mathrm{N}, 64^{\circ} \mathrm{E}\right)$ showed that this ratio varied from 0.6 to 5.5 (Kumar et al. 2001). These seasonal differences were due to low annual variability of mesozooplankton biomass (ranging from 1.5 to $2.2 \mathrm{~g} \mathrm{C} \mathrm{m}^{-2}$ ) although phytoplankton biomass varied from 0.4 to $2.2 \mathrm{~g} \mathrm{C} \mathrm{m}^{-2}$. Between $24^{\circ} \mathrm{N}$ and 10 to $15^{\circ} \mathrm{N}$ phytoplankton varied from 1.1 to $2.2 \mathrm{gC} \mathrm{m}^{-2}$ during the southwest monsoon, and from 1.3 to $1.5 \mathrm{gC}$ $\mathrm{m}^{-2}$ in the northeast monsoon (Shalopyonok et al. 2001). At that phytoplankton concentration, mesozooplankton biomass should be 0.5 to $0.8 \mathrm{~g} \mathrm{C} \mathrm{m}^{-2}$, according to Eq. (5). Annually averaged mesozooplankton biomass is in the range from 0.75 to $1 \mathrm{gC} \mathrm{m}^{-2}$ (Rudjakov et al. 1997).

Table 4. Averaged primary production, phyto-, mesozooplankton biomass and rates of primary production to phytoplankton biomass over the biogeochemical provinces of the Atlantic Ocean. PP: primary production from Longhurst et al. (1995); Phyto: phytoplankton biomass (0-100 m); MZ: mesozooplankton biomass $(0-100 \mathrm{~m})$

\begin{tabular}{|lcccc|}
\hline Province & \multicolumn{5}{c|}{$\begin{array}{c}\text { Mean annual values } \\
\end{array}$} & $\begin{array}{c}\mathrm{PP} \\
\text { Phyto }\end{array}$ & $\begin{array}{c}\text { PP:Phyto } \\
\mathrm{gC} \mathrm{m}^{-2} \mathrm{~d}^{-1}\end{array}$ & $\mathrm{~g} \mathrm{C} \mathrm{m}^{-2}$ & $\mathrm{~d}^{-1}$ & $\mathrm{~g} \mathrm{C} \mathrm{m}^{-2}$ \\
\hline West and east & 0.30 & 1.20 & 0.25 & 0.28 \\
$\quad$ subtropical gyre & & & & \\
Tropical gyre & 0.29 & 1.17 & 0.25 & 0.74 \\
Western tropical Atlantic & 0.36 & 1.26 & 0.29 & 0.80 \\
$\begin{array}{l}\text { Eastern tropical Atlantic } \\
\text { South Atlantic gyre }\end{array}$ & 0.43 & 1.32 & 0.32 & 0.96 \\
Coastal provinces & 0.21 & 1.04 & 0.20 & 0.24 \\
& 1.4 & 2.50 & 0.56 & 1.5 \\
\hline
\end{tabular}


Overall, in the upper $100 \mathrm{~m}$ layer, in the 6 studied provinces (Table 4) the mesozooplankton comprises approximately $50 \%$ of phytoplankton biomass. This layer is the major biotope for phytoplankton algae. In the tropical regions of the Atlantic Ocean, the ratio between mesozooplankton biomass in the $0-100 \mathrm{~m}$ to 0-500 m layer was equal to 0.5-0.7 (Lenz et al. 1993). If we accept an average value of 0.6 , then it can be said that phyto- and mesozooplankton biomass are approximately equal in the upper $500 \mathrm{~m}$ layer.

\section{Chlorophyll-zooplankton relations}

Correlation between chlorophyll in the upper $5 \mathrm{~m}$ and chlorophyll, phytoplankton, and mesozooplankton biomass in the 0 to $200 \mathrm{~m}$ layer were calculated for the Pacific $\left(40^{\circ} \mathrm{N}\right.$ to $\left.40^{\circ} \mathrm{S}\right)$ and the Atlantic Ocean $\left(20^{\circ} \mathrm{N}\right.$ to $\left.40^{\circ} \mathrm{S}\right)$. Estimates of phyto- and mesozooplankton were made at the same stations and usually from the same (180 l) bottles sampled at 12 to 24 depths in the upper $200 \mathrm{~m}$ layer (Vinogradov et al. 1999). According to their calculations, equation parameters were as follows:

$$
\begin{gathered}
B_{\mathrm{MZ}}=1.16 \mathrm{chl}^{0.433} \\
\left(\mathrm{r}^{2}=0.52, \mathrm{p}=0.0000, \mathrm{n}=99\right. \\
B_{\mathrm{P}}=1.47 \mathrm{chl}^{0.448} \\
\left(\mathrm{r}^{2}=0.46, \mathrm{p}=0.0000, \mathrm{n}=95\right. \\
\operatorname{chl}_{(0-200)}=49.43 \mathrm{chl}^{0.374} \\
\left(\mathrm{r}^{2}=0.67, \mathrm{p}=0.0000, \mathrm{n}=92\right.
\end{gathered}
$$

where $B_{\mathrm{P}}$ and $B_{\mathrm{Mz}}$ are phyto- and mesozooplankton biomass in $\mathrm{g} \mathrm{C} \mathrm{m}^{-2}$ (0 to $200 \mathrm{~m}$ ), Chl is chlorophyll concentration in the upper $5 \mathrm{~m}$ layer $\left(\mathrm{mg} \mathrm{m}^{-3}\right), \mathrm{Chl}_{(0-200)}$ is chlorophyll concentration in the upper $200 \mathrm{~m}$ layer $\left(\mathrm{mg} \mathrm{m}^{-2}\right.$ ). From Eqs. (7) and (8) one notices that $B_{\mathrm{Mz}}$ does not increase linearly with $B_{\mathrm{P}}$. Dividing Eq. (7) by Eq. (8), then the $B_{\mathrm{MZ}}$ : $B_{\mathrm{P}}$ ratio would not depend upon phytoplankton in the range from 0.2 to $4.0 \mathrm{~g} \mathrm{C} \mathrm{m}^{-2}$ and the derived ratio would be approximately 0.8 . These Pacific-related values are somewhat higher than those observed in the Atlantic Ocean. However, in the Pacific Ocean they are for the 200 m layer. For the Pacific Ocean regions, the ratio of mesozooplankton biomass through different depths (sampled layers) was quantified by the equation (Tseitlin et al. 1997a):

$$
k=\left(z_{1} / z_{2}\right)^{0.48}
$$

where $k$ is the coefficient transferring biomass in the $0-Z_{2} \mathrm{~m}$ layer into the biomass in the $0-z_{1} \mathrm{~m}$ layer. According to this equation, biomass $\left(\mathrm{mg} \mathrm{m}^{-2}\right.$ wet biomass) in the $200 \mathrm{~m}$ layer is 1.4 times higher than that in the $100 \mathrm{~m}$ layer. When the major phytoplankton biomass is in the $100 \mathrm{~m}$ layer, the ratio $B_{\mathrm{Mz}}: B_{\mathrm{P}}$ will be 0.6 .
This ratio results from Eq. (7) being divided by 1.4, and this figure being further divided by Eq. (8). The value is close to the values obtained for NATR, WTRA, ETRA, and GUN. However, it is 2 to 3 times higher than that in NAST and SATL. Differences are due to estimates of phytoplankton biomass. Eqs. (8) \& (9) indicate that in the $200 \mathrm{~m}$ layer, the chlorophyll:carbon (chl:c) ratio decreases from 0.04 to 0.03 with an increase of chlorophyll concentration from 0.05 to $5.0 \mathrm{mg}$ $\mathrm{m}^{-3}$ in the upper layer. These data do not corroborate well with a stated concept of nutrient impact on chlorophyll concentration (Geider et al. 1997). When phytoplankton is limited by nutrients the chl:c ratio decreases. In oligotrophic waters this ratio differs from that measured in the other oceanic regions.

In nutrient-depleted tropical waters, such as the north Pacific Ocean, the chl:c ratio within the mixed layer was 0.008 and declined to 0.04 at greater depth (Campbell et al. 1994). The values do not strongly diverge from the data obtained in the Atlantic Ocean on chlorophyll concentration and phytoplankton biomass in June (1992) in the EUMELI programme. During this period the sum of chl $a$ and divinyl-chl $a$ in oligotrophic waters was $34.6 \mathrm{mg} \mathrm{m}^{-2}$ and phytoplankton biomass measured with the flow cytometer on cell abundance and carbon content in the cell was $2.0 \mathrm{~g} \mathrm{C}$ $\mathrm{m}^{-2}$ (Partensky et al. 1996). The comparison of these values results in a chl:c in oligotrophic waters of 0.017 . From the above data one can assume that the phytoplankton biomass in oligotrophic regions, as reported by Vinogradov et al. (1999), is underestimated by 2 to 3 times.

Shushkina et al. (1997, their Table 1) summarised the annual data on average plankton biomass in the World's Ocean. They presented average data which suggest that where chl a from satellites is $<0.1 \mathrm{mg} \mathrm{m}^{-3}$, phytoplankton biomass is $0.42 \mathrm{~g} \mathrm{C} \mathrm{m}^{-2}$ and mesozooplankton is $0.3 \mathrm{~g} \mathrm{C} \mathrm{m}^{-2}$ in the upper $200 \mathrm{~m}$ layer of tropical oligotrophic waters. In the case of mesotrophic waters, values were 0.1 to $0.3 \mathrm{mg} \mathrm{m}^{-3}$ for chl $a, 0.56 \mathrm{~g} \mathrm{C}$ $\mathrm{m}^{-2}$ for phytoplankton and $0.95 \mathrm{gC} \mathrm{m}^{-2}$ for mesozooplankton. The mesozooplankton biomass exceeded that of phytoplankton according to these data in mesotrophic regions. The annual average mesozooplankton biomass we obtained for these chlorophyll concentrations (i.e. 0.1 to $0.3 \mathrm{mg} \mathrm{m}^{-3}$ ) was 0.45 and $0.90 \mathrm{~g} \mathrm{C} \mathrm{m}^{-2}$. These values were obtained as follows. Using Eq. (1) we determined the total chlorophyll value in the 0 to $100 \mathrm{~m}$ layer. This value was multiplied by 60 which gave phytoplankton biomass in carbon units $\left(\mathrm{g} \mathrm{C} \mathrm{m}^{-2}\right)$. These values were substituted in Eq. (5) $\&(6)$ in order to obtain zooplankton biomass in carbon units for 2 seasons. The annual mean was obtained from the above numbers. This mean corresponds fairly well with the estimate given by Shushkina et al. (1997). 
The mesozooplankton:phytoplankton ratio is different, which also is due to discrepancy in estimates of the phytoplankton biomass. Thus, if the chl a concentration per unit surface is calculated by Eq. (9) and divided by the phytoplankton biomass given by Shushkina et al. (1997), the chl a to carbon ratio is 0.03 for ultra-oligotrophic and 0.05 for mesotrophic regions. This level has only been observed for phytoplankton at the lower part of the photosynthetic zone (Furuya 1990, Li et al. 1992, Campbell et al. 1994). In the upper $10 \mathrm{~m}$ layer, with low nutrients, values of the chl $a$ to carbon ratio achieve 0.01 to 0.007 (Buck et al. 1996, Taylor et al. 1997) and were on average 0.015 for the $200 \mathrm{~m}$ layer.

\section{Seasonal cycles}

Cushing (1975) has postulated that there are 3 patterns of seasonal cycles in phyto-zooplankton relationships. The first is seen in Antarctic waters, where there is 1 summer peak of phyto- and zooplankton. The second is typical for temperate regions, where there are 2 peaks, a major one in spring and a less developed one in autumn. The seasonal peaks are not well developed in the third type, which is typical for tropical regions. We have analysed seasonal changes of primary production by Longhurst (1998), phyto- and mesozooplankton biomass in carbon units (Fig. 7) using remotely sensed seasonal measurements of chl a from the upper layer (Longhurst 1995) and mesozooplankton:chl a ratios (Fig. 5). In order to do that, an average surface concentration was calculated for the upper $100 \mathrm{~m}$ layer and multiplied by 60. From Eqs. (3) to (6), mesozooplankton biomass was calculated for each province. These enabled an estimate to be calculated of the dynamics of the biomass in tropical regions where field data are scarce. It should be noticed that the sharp decline of the curves between summer to winter seasons in Fig. 7 is related to the method of data analysis, where only 2 (i.e. not all 4) seasons were defined.

The maximum of phyto and zooplankton biomass in the province of the NAST and SATL occurs in the winter-spring period. During this time, the phyto- plankton biomass (1.2 to $1.8 \mathrm{gC} \mathrm{m}^{-2}$ ) was 1.5 to 2.0 times greater than that in the summer-autumn period, and for zooplankton biomass about 2 times. Similar seasonal patterns of zooplankton biomass have been reported for the Sargasso Sea, near Bermuda (Menzel \& Ryther 1961, Madin et al. 2001) and for the northwestern Atlantic Ocean (40 to $45^{\circ} \mathrm{N}$ ), based on copepod abundance measurements (Planque et al. 1997). The measurements of phytoplankton biomass are in reasonable agreement with the chl a data. From a transect carried out in August to September from $20^{\circ} \mathrm{W}$,
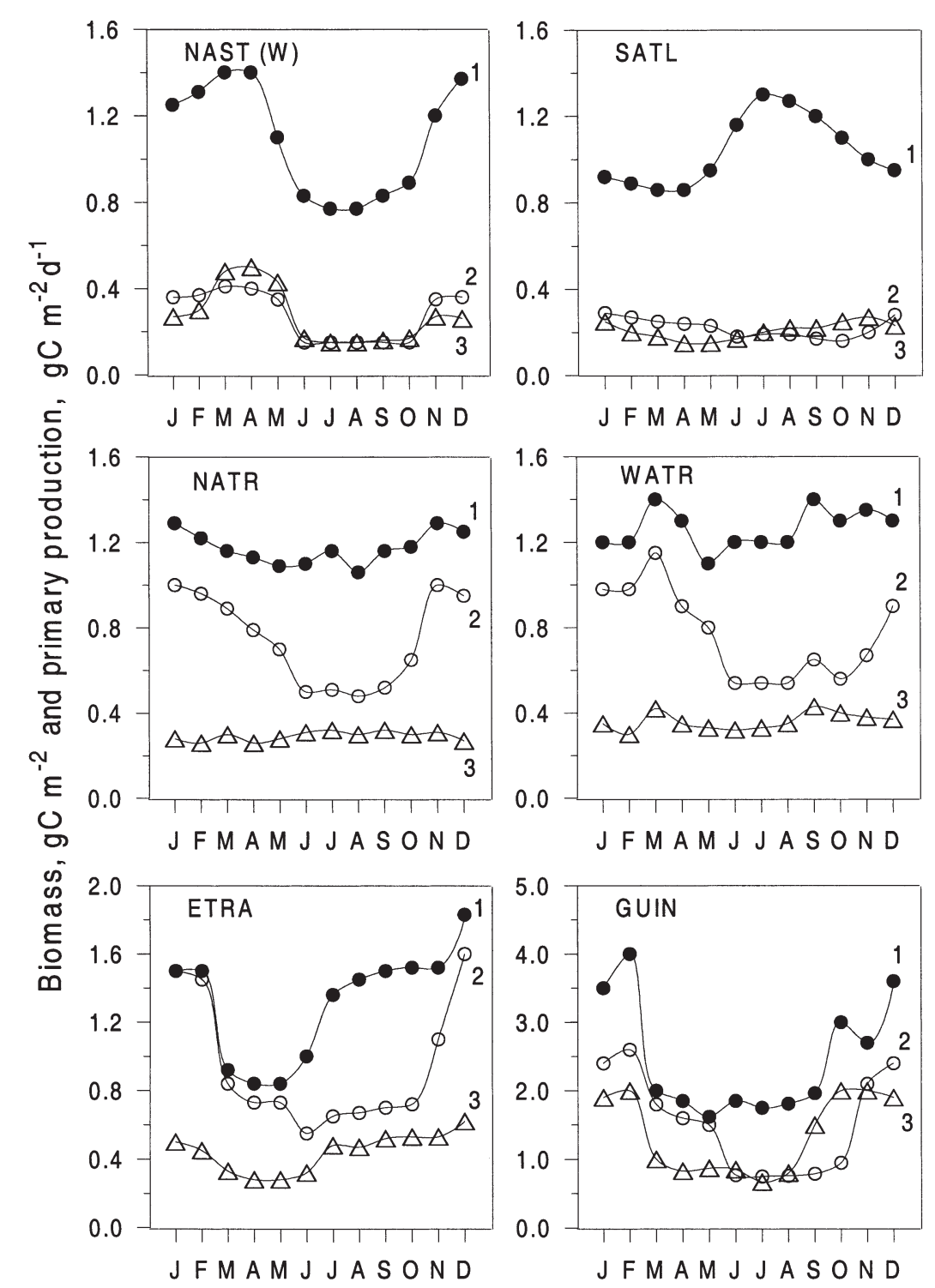

Fig. 7. Seasonal cycle of primary production (3) described by Longhurst (1998) and phyto- (1) and mesozooplankton (2) biomass in individual provinces calculated with Eqs. (1) to (6) from the CZCS chlorophyll concentration (Longhurst 1995) 
between $25^{\circ}$ and $45^{\circ} \mathrm{N}$, Buck et al. (1996) quantified the phytoplankton biomass as $1.07 \mathrm{gC} \mathrm{m}^{-2}$. They achieved this by counting the algae using a flow cytometer, and from carbon measurements of individual cells. We calculated the phytoplankton biomass from the chl a August values as $0.92 \mathrm{gC} \mathrm{m}^{-2}$ (Fig. 7). Mesozooplankton biomass was measured as $0.82 \mathrm{gC}$ $\mathrm{m}^{-2}$, in April, along $20^{\circ} \mathrm{W}$ at $33^{\circ} \mathrm{N}$ by Lenz et al. (1993), and when calculated from the chl a values it was $0.6 \mathrm{~g} \mathrm{C} \mathrm{m}^{-2}$. Similar values of mesozooplankton biomass $\left(0.4 \mathrm{~g} \mathrm{C} \mathrm{m}^{-2}\right)$ and phytoplankton biomass $(1.4 \mathrm{gC}$ $\left.\mathrm{m}^{-2}\right)$ were obtained for the northern province $\left(20^{\circ} \mathrm{W}\right.$, $47^{\circ} \mathrm{N}$ ) at the end of April (Harrison et al. 1993, Lochte et al. 1993).

Seasonal variations of phytoplankton and mesozooplankton biomass over the year do not exceed 2 times in the provinces of the western and tropical gyres (Fig. 7). In these provinces, where a weak upwelling takes place, the production cycle for biomass has a low amplitude. In the eastern tropical ocean, where seasonal changes of upwelling and hydrographic conditions are well developed (Longhurst 1993), changes in phyto- and mesozooplankton can reach 2- to 3-fold (Fig. 7). Minimal values of zooplankton biomass were observed in March to May (0.4 to $0.6 \mathrm{gC} \mathrm{m}^{-2}$ ) and increased in December to $1.6 \mathrm{~g} \mathrm{C} \mathrm{m}^{-2}$. Gruzov (1973) and Borgne (1977) reported similar seasonal cycles for this region. From the equator to $12^{\circ} \mathrm{S}$, zooplankton biomass changes from 0.3 to $0.6 \mathrm{~g} \mathrm{C} \mathrm{m}^{-2}$ during spring and by the end of autumn it was 1.0 to $1.5 \mathrm{gC} \mathrm{m}^{-2}$. The characteristic seasonal cycles in the phytoplankton biomass are in good agreement with the large-scale changes of primary production and mesozooplankton biomass.

In general, our analysis indicated that the seasonal dynamics of phyto- and mesozooplankton biomass were fairly similar in the subtropical and tropical provinces. Differences are observed in the amplitude of biomass fluctuations, which are greater in regions where nutrient enrichment takes place in the upper layer. For the large area of the eastern tropical Pacific, logarithmic values of primary production, chlorophyll and mesozooplankton biomass were positively correlated with each other in each season and area (Blackburn 1981). The main point of interest is that the phytoand mesozooplankton biomass seasonal changes were generally similar and small in the tropical Atlantic and Pacific Oceans.

\section{Phytoplankton specific production}

Estimates of the plankton biomass of the World's Ocean have a useful role for assessments of the carbon cycle. Annual values of phytoplankton production among oceanic provinces range from 0.2 to $0.4 \mathrm{~g} \mathrm{C} \mathrm{m}^{-2}$ $\mathrm{d}^{-1}$ (Table 4). This carbon flux is driven by a phytoplankton biomass of 1.0 to $1.3 \mathrm{~g} \mathrm{C} \mathrm{m}^{-2}$. On average, phytoplankton biomass in the oceanic provinces turns over once per 3 to $5 \mathrm{~d}$. The specific daily production of phytoplankton (yearly average) is relatively constant over different latitudes: it varies between 0.2 and $0.3 \mathrm{~d}^{-1}$ in the upper $100 \mathrm{~m}$ layer. In coastal provinces, where the concentration of nutrients is high, the specific production is higher, at $0.5 \mathrm{~d}^{-1}$. Therefore, mesozooplankton biomass might differ several times with the same primary production level.

\section{CONCLUSION}

The concept of biogeochemical provinces was applied to the field measurements on chlorophyll and mesozooplankon in the tropical and subtropical regions obtained in the past $40 \mathrm{yr}$. This allowed us to derive trends of mesozooplankton-phytoplankton relationships within the provinces, which could be used to restore macroscale mesozooplankton biomass distributions from remotely sensed chlorophyll data.

General patterns were obtained between chlorophyll concentrations and mesozooplankton biomass on an ocean basin scale. The ratio of the total biomass of phyto- and mesozooplankton, in carbon units, varied from 6 to 1 in the 0 to $100 \mathrm{~m}$ layer and on average, the phytoplankton biomass exceeded twice that of mesozooplankton. The seasonal cycles of phyto- and zooplankton biomass for the 6 provinces of the tropical and subtropical zones were qualitatively comparable. There were nonlinear relationships between mean chlorophyll concentration within the 0 to $10 \mathrm{~m}$ layer and mesozooplankton biomass within the 0 to $100 \mathrm{~m}$ layer, which indicated that a different amount of phytoplankton carbon biomass corresponds to mesozooplankton biomass. In the moderate productive regions, the amount of mesozooplankton carbon biomass per unit of phytoplankton carbon would be higher than in oligotrophic regions. Relationships were established between primary production, phytoplankton and mesozooplankton biomass for the 6 oceanic provinces.

Acknowledgements. This work was funded by NSF grant \#DEB-0203622, NASA grant \#NAG 5-3113 and the UK Darwin Initiative grant \#162/8/251.

\section{LITERATURE CITED}

ATLANTNIRO Archives (1978) Cruise Report of the BMRT 'Estafeta Oktyabra'. ATLANTNIRO, Kaliningrad (in Russian) 
Banse K (1994) Grazing and zooplankton production as key controls of phytoplankton production in the open ocean. Oceanography 7:13-20

Banse K, English DC (1994) Seasonality of coastal zone color scanner phytoplankton pigment in the offshore oceans. J Geophys Res 99:7323-7345

Bé AWH, Forns JM, Roels OA (1971) Plankton abundance in the North Atlantic Ocean. In: Costlow JD (ed) Fertility of the sea. Gordon \& Breach Publishers, New York, p 17-50

Bender ML, Ducklow W, Kiddon J, Marra J, Martin JH (1992) The carbon balance during the 1989 spring bloom in the North Atlantic Ocean at $47^{\circ} \mathrm{N}, 20^{\circ} \mathrm{W}$. Deep Sea Res I 39: $1707-1725$

Berger WH (1989) Global maps of ocean productivity. In: Berger WH, Smetacek VS, Wfer G (eds) Productivity of the ocean present and past. John Wiley \& Sons, New York, p 429-455

Bezrukov Yr (1989) The structure hydrological of the waters in the northwest tropical Atlantic. Mar Hydrophys J 25: 40-46 (in Russian)

Blackburn M (1981) Low latitude gyral regions. In: Longhurst AR (ed) Analysis of marine ecosystems. Academic Press, New York, p 3-29

Bode A, Barquero S, Varela M, Braun JG, deArmas D (2001) Pelagic bacteria and phytoplankton in oceanic waters near the Canary Islands in summer. Mar Ecol Prog Ser 209:1-17

Bogorov BG, Vinogradov ME, Voronina NM, Kanaeva IP, Suetova IA (1968) Distribution of zooplankton biomass in the surface layer of the World Ocean. Dokl Akad Nauk SSSR 182:1205-1208 (in Russian)

Borgne R (1977) Étude de la production pelagique de la zone equatoriale de l'Atlantique a $4^{\circ} \mathrm{W}$. Respiration et excretion d'azote et de phosphore du zooplancton. Cah ORSTOM Océanogr 15:349-362

Buck KR, Chavez FP, Campbell L (1996) Basin-wide distribution of living carbon components and the inverted trophic pyramid of the central gyre of the North Atlantic Ocean, summer 1993. Aquat Microb Ecol 10:283-298

Burkill PH, Edwards ES, John AWG, Sleigh MA (1993) Microzooplankton and their herbivorous activity in the northeastern Atlantic Ocean. Deep Sea Res II 40:479-493

Calbet A (2001) Mesozooplankton grazing effect on primary production: a global comparative analysis in marine ecosystems. Limnol Oceanogr 46(7):1824-1830

Campbell L, Nolla HA, Vaulot D (1994) The importance of Procholorococcus to community structure in the central North Pacific Ocean. Limnol Oceanogr 39:1122-1140

Chromov NS (1962) Distribution and dynamics of the plankton and feeding of Sardinella in the fishery regions of the western coasts of Africa. Trudy Vses Naychn Inst Morsk Rybn Hoz Okeanogr 46, C7:204-235 (in Russian)

Chromov NS (1965) Some data on the plankton of the DakarFreetown region (data of the 10th and 12th cruises of the RV Michael Lomonosov, 1961-1962). Trudy Vses Naychn Inst Morsk Rybn Hoz Okeanogr 57:47-69 (in Russian)

Chromov NS (1986) Some peculiarities of the plankton quantitative distribution in the Atlantic Ocean. In: Moiseev PA, Parin NV, Elizarov AA (eds) Biologicheskie resyrsy Atlantichekogo okeana Nauka, Moscow, p 157-175 (in Russian)

Corcoran EF, Manken CVW (1969) Productivity of the Tropical Atlantic Ocean. In: Proc Symp Oceanogr Fish Res Tropical Atlantic. UNESCO-FAO, Paris, p 57-67

Cressie NAC (1991) Statistics for spatial data. John Wiley \& Sons, New York

Cushing DH (1975) Marine ecology and fisheries. Cambridge University Press, Cambridge
Dam HG, Miller CA, Jonasdottir SH (1993) The trophic role of mesozooplankton at $47^{\circ} \mathrm{N}$ during the North Atlantic Bloom Experiment. Deep Sea Res II 40:197-212

Eppley RW, Stewart E, Abbot MR, Heyman U (1985) Estimating ocean primary production from satellite chlorophyll. Introduction to regional differences and Statistics for the Southern California Bight. J Plankton Res 7:57-70

Eppley RW, Stewart E, Abbott MR, Owen RW (1987) Estimating ocean production from satellite-derived chlorophyll: insights from the Eastropac data set. Oceanol Acta Proc, Intern Symp Equatorial Vertical Motion, Paris, 6-10 May 1985. ORSTOM, Paris, p 109-113

Falkowski PG, Barber RT, Smetacek V (1998) Biogeochemical controls and feedbacks on Ocean primary production. Science 281:200-206

Fasham MJR, Boyd PW, Savidge G (1999) Modeling the relative contributions of autotrophs and heterotrophs to carbon flow at a Lagrangian JGOFS station in the Northeast Atlantic: the importance of DOC. Limnol Oceanogr 44: 80-94

Finenko ZZ (1978) Production in plant populations. In: Kinne O (ed) Marine ecology, Vol. 1. John Wiley \& Sons, New York, p 13-87

Finenko ZZ (1994) Satellite determination of the vertical structure of phytoplankton biomass and primary production in the north east Atlantic ocean. Tech Note No. 1.94.135. Commission of the European Communities. Institute for Remote Sensing Applications, Ispra, p 1-27

Furuya K (1990) Subsurface chlorophyll maximum in the tropical and subtropical western Pacific Ocean: vertical profiles of phytoplankton biomass and its relationship with chlorophyll $a$ and particulate organic carbon. Mar Biol 107:529-539

Galbert A, Agusti S (1999) Latitudinal changes of copepod egg producton rates in Atlantic waters: temperature and food availability as the main driving factors. Mar Ecol Prog Ser 181:155-162

Gallienne CP, Robins DB (1998) Trans-oceanic characterization of zooplankton community size structure using an optical plankton counter. Fish Oceanogr 7:147-158

Gasol JM, Giorgio PA, Duarte CM (1997) Biomass distribution in marine planktonic communities. Limnol Oceanogr 42 : 1353-1363

Geider RJ, MacIntyre L, Kana TM (1997) A dynamic model of phytoplankton growth and acclimation: responses of the balanced growth rate and the chlorophyll a: carbon ratio to light, nutrient-limitation and temperature. Mar Ecol Prog Ser 148:187-200

Gibbons MJ, Hutchings L (1996) Zooplankton diversity and community structure around southern Africa, with special attention to the Benguela upwelling system. S Afr J Sci 92: $63-76$

Greze VN (1971) The biological structure and productivity of the tropical Atlantic pelagial. In: Greze VN (ed) The plankton and biological productivity of the tropical Atlantic. Naukova Dumka, Kiev, p 214-252 (in Russian)

Greze VN, Latun VS, Novoselov AA, Sheremetieva AI and 25 others (1984) The bioproductive system of the large-scale oceanic gyre. Naukova Dumka, Kiev (in Russian)

Gruzov LN (1973) The productive zone of the equatorial Atlantic: description and condition of its formation. In: Shuleikin VV (ed) Tropical zone of the World Ocean and associated global processes. Nauka, Moscow, p 258-266

Harrison WG, Head EJH, Horne EPW, Irwin B, Li WKW, Longhurst AR, Paranjape MA, Platt T (1993) The western North Atlantic bloom experiment. Deep Sea Res II 40:279-305

Hoepffner N, Sturm B, Finenko Z, Larkin D (1999) Depth- 
integrated primary production in the eastern tropical and subtropical North Atlantic basin from ocean colour imagery. Int J Remote Sens 20:1435-1456

Huskin I, Anadon R, Woodd-Walker RS, Harris RP (2001a) Basin-scale latitudinal patterns of copepod grazing in the Atlantic Ocean. J Plankton Res 23(12):1361-1371

Huskin I, Anadon R, Medina G, Head RN, Harris RP (2001b) Mesozooplankton distribution and copepod grazing in the subtropical Atlantic near the Azores: influence of mesoscale structures. J Plankton Res 23(7):671-691

IBSS Archives (1977) Report of the 3rd cruise of RV 'Professor Vodyanitsky'. Institute of Biology of the Southern Seas, Sevastopol (in Russian)

IBSS Archives (1979) Report of the 5th cruise of RV 'Professor Vodyanitsky'. Institute of Biology of the Southern Seas, Sevastopol (in Russian)

IBSS Archives (1980) Report of the 7th cruise of RV 'Professor Vodyanitsky'. Institute of Biology of the Southern Seas, Sevastopol (in Russian)

IBSS Archives (1982a) Report of the 11th cruise of RV 'Professor Vodyanitsky'. Institute of Biology of the Southern Seas, Sevastopol (in Russian)

IBSS Archives (1982b) Report of the 13th cruise of RV 'Professor Vodyanitsky'. Institute of Biology of the Southern Seas, Sevastopol (in Russian)

IBSS Archives (1985a) Report of the 18th cruise of RV 'Professor Vodyanitsky'. Institute of Biology of the Southern Seas, Sevastopol (in Russian)

IBSS Archives (1985b) Report of the 20th cruise of RV 'Professor Vodyanitsky'. Institute of Biology of the Southern Seas, Sevastopol (in Russian)

IBSS Archives (1986) Report of the 21st cruise of RV 'Professor Vodyanitsky'. Institute of Biology of the Southern Seas, Sevastopol (in Russian)

IBSS Archives (1987) Report of the 24th cruise of RV 'Professor Vodyanitsky'. Institute of Biology of the Southern Seas, Sevastopol (in Russian)

IBSS Archives (1989) Report of the 29th cruise of RV 'Professor Vodyanitsky'. Institute of Biology of the Southern Seas, Sevastopol (in Russian)

Jeffrey SW, Humphrey GF (1975) New specrophotometric equations for determining chlorophylls $\mathrm{a}, \mathrm{b}, \mathrm{c}_{1}, \mathrm{c}_{2}$ in higher plants and phytoplankton. Biochem Physiol Pflanz (BPP) 167:191-194

Jeffrey SW, Mantoura RFC, Bjørnland T (1997) Data for the identification of 47 key phytoplankton pigments. In: Jeffrey SW, Mantoura RFC, Wright SW (eds) Phytoplanktonpigments in oceanography guide lines to modern methods. UNESCO Publishing, Paris, p 447-560

Kanaeva IP (1962) First results of the Soviet plankton research in the Atlantic Ocean along the IGY and IGS programs. Trudy Vses Naychn Inst Morsk Rybn Hoz Okeanogr 46: 201-214 (in Russian)

Kanaeva IP (1973) Quantitative distribution of the plankton in the tropical region of the Atlantic Ocean (southern part). In: Tropical zone of the World's Ocean and associated global processes. Moscow, Nauka, p 288-292 (in Russian)

Koblentz-Mishke OI, Volkovinsky VV, Kabanova YuG (1970) Recent data on the quantity of primary production of the world ocean. Dokl Akad Nauk SSSR 183:1189-1192 (in Russian)

Kolesnikov AN, Kovaleva TN (1973) Some peculiarities of the plankton distribution in the tropical Atlantic. Biol Morya 28:85-93 (in Russian)

Kovalevskaya NV, Lubnyi-Gercik EA, Pasternak FA (1968) Biological research in the first pilot cruise of RV 'Akademician Kurchatov'. Okeanologiya 8:169-171 (in Russian)
Kumar SP, Ramaiah N, Gauns M, Sarma VVSS and 5 others (2001) Physical forcing of biological productivity in the Northern Arabian sea during the Northeast Monsoon. Deep Sea Res II 48:1115-1126

Lenz J, Morales A, Gunkel J (1993) Mesozooplankton standing stock during the North Atlantic spring bloom study in 1989 and its potential grazing pressure on phytoplankton: a comparison between low, medium and high latitudes. Deep Sea Res II 40:559-572

Li WKW (1995) Composition of ultraphytoplankton in the central North Atlantic. Mar Ecol Prog Ser 122:1-8

Li WKW, Dickie PM, Irwin BD, Wood AM (1992) Biomass of bacteria, cyanobacteria, prochlorophytes and photosynthetic eukaryotes in the Sargasso Sea. Deep Sea Res II 39: 501-519

Li WKW, Dickie PM, Harrison WG, Irwin BD (1993) Biomass and production of bacteria and phytoplankton during the spring bloom in the western North Atlantic. Deep Sea Res II 40:307-328

Lochte K, Ducklow HW, Fasham MJR, Stienen C (1993) Plankton succession and carbon cycling at $47^{\circ} \mathrm{N}, 20^{\circ} \mathrm{W}$ during the JGOFS North Atlantic bloom experiment. Deep Sea Res II 40:91-114

Longhurst AR (1993) Seasonal cooling and blooming in tropical oceans. Deep Sea Res I 40:2145-2165

Longhurst AR (1995) Seasonal cycles of pelagic production and consumption. Prog Oceanogr 36:77-167

Longhurst AR (1998) Ecological geography of the Sea. Academic Press, London

Longhurst AR, Harrison G (1989) The biological pump: profiles of plankton production and consumption in the upper ocean. Prog Oceanogr 22:47-123

Longhurst AR, Sathyendranath S, Platt T, Caverhill C (1995) An estimate of global primary production in the ocean from satellite radiometer data. J Plankton Res 17: $1245-1271$

Lorenzen CJ (1970) Surface chlorophyll as an index of the depth, chlorophyll content, and primary productivity of the euphotic layer. Limnol Oceanogr 38:1646-1665

Lubni-Gercik EP (1972) To the plankton of the western tropical zone of the Atlantic Ocean in connection with peculiarities of hydrological regime. Okeanologiya 12:364-367 (in Russian)

Lubni-Gercik EP (1975) Planktonic research in the regions of the Carribean Sea and the Puerto-Rico valley (JanuaryMarch, 1973). Trudy PP Shirshov Inst Okeanol Akad Nauk SSSR 101:35-39

Madin LP, Horgan EF, Steinberg DK (2001) Zooplankton at the Bermuda Atlantic Time-series Study (BATS) station: diel, seasonal and interannual variation in biomass, 1994-1998. Deep-Sea Res II 48:2063-2082

McClain CR, Esaias WE, Feldman GC, Elrod J and 5 others (1990) Physical and biological processes in the North Atlantic during the first GARP global experiment. J Geophys Res 95:18027-18048

Menzel DW, Ryther JH (1961) Zooplankton in the Sargasso Sea off Bermuda and its relation to organic production. J Cons Perm Int Explor Mer 26:250-258

MHI Archives (1963) Report of the 14th cruise of RV 'Michael Lomonosov'. Marine Hydrophysical Institute, Sevastopol (in Russian)

MHI Archives (1964) Report of the 15th cruise of RV 'Michael Lomonosov'. Marine Hydrophysical Institute, Sevastopol (in Russian)

MHI Archives (1965) Report of the 17th cruise of RV 'Michael Lomonosov'. Marine Hydrophysical Institute, Sevastopol (in Russian) 
MHI Archives (1970) Report of the 3rd cruise of RV 'Academician Vernadsky'. Marine Hydrophysical Institute, Sevastopol (in Russian)

MHI Archives (1972) Report of the 26th cruise of RV 'Michael Lomonosov'. Marine Hydrophysical Institute, Sevastopol (in Russian)

MHI Archives (1974a) Report of the 8th cruise of RV 'Akademician Vernadsky'. Marine Hydrophysical Institute, Sevastopol (in Russian)

MHI Archives (1974b) Report of the 28th cruise of RV 'Michael Lomonosov'. Marine Hydrophysical Institute, Sevastopol (in Russian)

MHI Archives (1974c) Report of the 9th cruise of RV 'Akademician Vernadsky'. Marine Hydrophysical Institute, Sevastopol (in Russian)

MHI Archives (1976) Report of the 13th cruise of RV 'Academician Vernadsky'. Marine Hydrophysical Institute, Sevastopol (in Russian)

MHI Archives (1977) Report of the 16th cruise of RV 'Academician Vernadsky'. Marine Hydrophysical Institute, Sevastopol (in Russian)

MHI Archives (1980a) Report of the 38th cruise of RV 'Mikhail Lomonosov'. Marine Hydrophysical Institute, Sevastopol (in Russian)

MHI Archives (1980b) Report of the 40th cruise of RV 'Mikhail Lomonosov'. Marine Hydrophysical Institute, Sevastopol (in Russian)

MHI Archives (1984a) Report of the 28th cruise of RV 'Academician Vernadsky'. Marine Hydrophysical Institute, Sevastopol (in Russian)

MHI Archives (1984b) Report of the 29th cruise of RV 'Academician Vernadsky'. Marine Hydrophysical Institute, Sevastopol (in Russian)

MHI Archives (1985) Report of the 32d cruise of RV 'Academician Vernadsky'. Marine Hydrophysical Institute, Sevastopol (in Russian)

MHI Archives (1986a) Report of the 34th cruise of RV 'Academician Vernadsky'. Marine Hydrophysical Institute, Sevastopol (in Russian)

MHI Archives (1986b) Report of the 47th cruise of RV 'Mikhail Lomonosov'. Marine Hydrophysical Institute, Sevastopol (in Russian)

MHI Archives (1987) Report of the 36th cruise of RV 'Academician Vernadsky'. Marine Hydrophysical Institute, Sevastopol (in Russian)

Monger B, McClain Ch, Murtugudde R (1997) Seasonal phytoplankton dynamics in the eastern tropical Atlantic. J Geophys Res 102:12389-12411

Moralis CE, Beod A, Harris RP, Tranter PRG (1991) Grazing of copepod assemblages in the north-east Atlantic: the importance of the small size fraction. J Plankton Res 13: $455-472$

Morel A, Berthon JF (1989) Surface pigments, algal biomass profiles, and potential production of the euphotic layer: relationships reinvestigated in view of remote-sensing applications. Limnol Oceanogr 34:1545-1562

NASA (1989) Ocean color from space, CZCS images and text prepared by NSF/NASA. Woods Hole Oceanographic Institute with contributions from the Goddard Space Flight Center, University of Miami and the University of Rhode Island. Woods Hole Oceanographic Institute, Woods Hole, MA

Neveux J, Lantoine F (1993) Spectrofluorometric assay of chlorophylls and pheopigments using least square approximation technique. Deep Sea Res I 40:1747-1765

Olson RJ, Chisholm SW, Zettler ER, Altabet MA, Dusenberry JA (1990) Spatial and temporal distributions of prochloro- phyte picoplankton in the North Atlantic Ocean. Deep Sea Res II 37:1033-1051

Partensky F, Blanchot F, Lantoine F, Neveux J, Marie D (1996) Vertical structure of picophytoplankton at different trophic sites of the tropical northeastern Atlantic Ocean. Deep Sea Res II 34:1191-1213

Piontkovski SA, Ignatyev SM (1992) Macroscale distribution of zooplankton biomass of the tropical Atlantic. Hydrobiol $28: 20-25$

Piontkovski SA, Williams R (1995) Multiscale variability of tropical ocean zooplankton biomass. ICES J Mar Sci 52: 643-656

Piontkovski SA, Tokarev YuN, Bityukov EP, Williams $\mathrm{R}_{\text {, }}$ Kiefer DA (1997) The bioluminescent field of the Atlantic Ocean. Mar Ecol Prog Ser 156:33-41

Planque B, Hays GC, Ibanez F, Gamble JC (1997) Large scale spatial variations in the seasonal abundance of Calanus finmarchicus. Deep Sea Res I 44:315-326

Platt T, Herman AW (1983) Remote sensing of phytoplankton in the sea: surface layer chlorophyll as an estimate of water-column chlorophyll and primary production. Int J Remote Sens 4:343-351

Rudjakov JA, Tseitlin VB, Kitain VJ (1997) Annual mean mesoplankton biomass distribution in the surface layer of the Indian Ocean. Oceanology 37:553-558

Semenova TB (1961) Qualitative and quantitative characteristic of the plankton in the fishery regions of DakarTakoradi. Tr BALTNIRO 7:34-37 (in Russian)

Semina G (1977) Phytoplankton. In: Vinogradov M (Ed) Biology of the ocean (Biologiya okeana), V.1. Nauka, Moscow, p 58-62 (in Russian)

Shalapyonok A, Olson RJ, Shalapyonok LS (2001) Arabian sea phytoplankton during Southwest and Northeast Monsoons 1995: composition, size structure and biomass from individual cell properties measured by flow cytometry. Deep Sea Res II 48:1231-11261

Shushkina EA, Vinogradov ME, Lebedeva LP, Anohina LL (1997) Production characteristics of epipelagic communities in the World Ocean. Oceanology 37:381-388

Smith RC (1981) Remote sensing and depth distribution of ocean chlorophyll. Mar Ecol Prog Ser 5:359-361

Sushchenya LM (1975) Quantitative patterns of crustacea grazing. Science and Techniques, Minsk (in Russian)

Taylor AH, Geider RJ, Gilbert JH (1997) Seasonal and latitudinal dependencies of phytoplankton carbon-to-chlorophyll a ratios: results of a modelling study. Mar Ecol Prog Ser 152:51-66

Tranter DJ (1973) Seasonal studies of a pelagic ecosystem (meridian $100^{\circ} \mathrm{E}$ ). In: Zeitzschel B (ed) The biology of the Indian Ocean. Chapman \& Hall, London, p 487-520

Tseitlin VB, Rudjakov JA, Kitain VJ (1997a) Distribution of zooplankton biomass in the surface layer of the Pacific. Oceanology 37:75-82

Tseitlin VB, Kitain VJ, Rudjakov JA (1997b) Annual mean mesoplankton biomass distribution in the surface layer of the Atlantic Ocean. Oceanology 37:666-671

Verity PG, Stoecker DK, Sieracki ME, Burkill PH, Edwards ES, Tronzo GR (1993) Abundance, biomass and distribution of heterotrophic dinoflagellates during the North Atlantic spring bloom. Deep Sea Res II 40:227-244

Vinogradov ME, Shushkina EA (1987) The functioning of the planctonic communities of the ocean epipelagia. Nesis KN (ed) Nauka, Moscow (in Russian)

Vinogradov ME, Shushkina EA, Nezlin NP, Vedernikov VI (1999) Correlation link between different ecosystem parameters of the Worlds Ocean epipelagic. Oceanology 39 $54-69$ 
Vladimirskaya EV (1972) Distribution and seasonal changes of zooplankton biomass of the north-western part of the Atlantic Ocean. Trudy Vses Naychn Inst Morsk Rybn Hoz Okeanogr 77(2):38-70 (in Russian)

Voituriez B (1981) Les sous-courants équatoriaux nord et sud et la formation des dômes thermiques tropicaux. Oceanol Acta 4:497-506

Voronina NM (1975) The ecology and biogeography of the plankton of the Southern Ocean. Trudy PP Shirshov Inst Okeanol Akad Nauk SSSR 103:60-87 (in Russian)

Wiebe PH. (1988) Functional regression equations for zooplankton displacement volume, wet weight, dry weight, and carbon: a correction. Fish Bull 86:833-835

Editorial responsibility: Otto Kinne (Editor),

Oldendorf/Luhe, Germany
Williams PJL (1981) Microbial contribution to overall marine metabolism: direct measurement of respiration. Oceanol Acta 4:359-364

Yashnov VA (1962) Plankton of the tropical region of the Atlantic Ocean. Tr Mors Gidrophys Inst 25:196-208 (in Russian)

Yoder JA, McClain CR, Feldman GC, Esaias WE (1993) Annual cycles of phytoplankton chlorophyll concentrations in the global ocean: a satellite view. Glob Biogeochem Cycles 7:181-193

Zernova AA (1974) Phytoplankton biomass distribution in the Atlantic Ocean tropical waters. Oceanology 6: 1070-1076

Submitted: November 24, 2000; Accepted: November 19, 2002 Proofs received from author(s): March 7, 2003 